\title{
Spatial distribution of the iron supply to phytoplankton in the Southern Ocean: a model study
}

\author{
C. Lancelot $^{1}$, A. de Montety ${ }^{2}$, H. Goosse ${ }^{2}$, S. Becquevort ${ }^{1}$, V. Schoemann ${ }^{1}$, B. Pasquer ${ }^{1, *}$, and M. Vancoppenolle ${ }^{2}$ \\ ${ }^{1}$ Université Libre de Bruxelles, Faculté des Sciences, Ecologie des Systèmes Aquatiques, Brussels, Belgium \\ ${ }^{2}$ Université catholique de Louvain, Institut d'astronomie et de géophysique Georges Lemaître, Louvain-La-Neuve, Belgium \\ *now at: Antarctic Climate and Ecosystems Cooperative Research Centre, Hobart, Australia
}

Received: 2 April 2009 - Published in Biogeosciences Discuss.: 12 May 2009

Revised: 30 October 2009 - Accepted: 2 November 2009 - Published: 7 December 2009

\begin{abstract}
An upgraded version of the biogeochemical model SWAMCO is coupled to the ocean-sea-ice model NEMOLIM to explore processes governing the spatial distribution of the iron supply to phytoplankton in the Southern Ocean. The 3-D NEMO-LIM-SWAMCO model is implemented in the ocean domain south of latitude $30^{\circ} \mathrm{S}$ and runs are performed over September 1989-December 2000. Model scenarios include potential iron sources (atmospheric deposition, iceberg calving/melting and continental sediments) as well as iron storage within sea ice, all formulated based on a literature review. When all these processes are included, the simulated iron profiles and phytoplankton bloom distributions show satisfactory agreement with observations. Analyses of simulations and sensitivity tests point to the key role played by continental sediments as a primary source for iron. Iceberg calving and melting contribute by up to $25 \%$ of Chl- $a$ simulated in areas influenced by icebergs while atmospheric deposition has little effect at high latitudes. Activating sea ice-ocean iron exchanges redistribute iron geographically. Stored in the ice during winter formation, iron is then transported due to ice motion and is released and made available to phytoplankton during summer melt, in the vicinity of the marginal ice zones. Transient iron storage and transport associated with sea ice dynamics stimulate summer phytoplankton blooming (up to $3 \mathrm{mg} \mathrm{Chl-} a \mathrm{~m}^{-3}$ ) in the Weddell Sea and off East Antarctica but not in the Ross, Bellingshausen and Amundsen Seas. This contrasted feature results from the simulated variable content of iron in sea ice and release of melting ice showing higher ice-ocean iron fluxes in the continental shelves of the Weddell and Ross Seas than in the Eastern Weddell Sea and the Bellingshausen-Amundsen
\end{abstract}

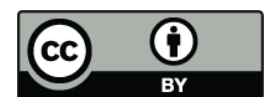

Correspondence to: C. Lancelot (lancelot@ulb.ac.be)
Seas. This study confirms that iron sources and transport in the Southern Ocean likely provide important mechanisms in the geographical development of phytoplankton blooms and associated ecosystems.

\section{Introduction}

The HNLC (High Nutrient Low Chlorophyll) nature of the modern Southern Ocean is attributed to the low availability of dissolved iron, an essential micronutrient for phytoplankton growth. Phytoplankton growth limitation by iron was demonstrated by iron-enriched bioassays (de Baar et al., 1990), in natural fertilization systems (de Baar et al., 1995; Blain et al., 2007; Pollard et al., 2009) as well as in the framework of in situ mesoscale iron release experiments (de Baar et al., 2005; Boyd et al., 2007). In a review of in situ iron-enriched experiments, de Baar et al. (2005) conclude that iron is necessary - but not sufficient - for phytoplankton blooms to occur. Another important factor is light availability within the upper mixed layer, which controls the onset and maintenance of the bloom, as already suggested in earlier studies (Smith and Nelson, 1985; Mitchell et al., 1991). Increased iron supply of atmospheric origin during glacial ages has been advanced as a potential explanation for intensified Southern Ocean biological pump, carbon uptake and reduced $\mathrm{CO}_{2}$ concentrations (Sigman and Boyle, 2000).

Close examination of seasonal surface Chl- $a$ distributions derived from the SeaWiFS satellite shows that Chl$a<0.5 \mathrm{mg} \mathrm{m}^{-3}$ (i.e. typical of HNLC waters) are indeed reported for ice-free surface waters in the remote deep ocean basins around Antarctica (Fitch and Moore, 2007; Arrigo et al., 2008). However, transient spots with relatively much higher concentrations ( $\sim 2-20 \mathrm{mg}$ Chl- $a \mathrm{~m}^{-3}$ ) are commonly

Published by Copernicus Publications on behalf of the European Geosciences Union. 
reported around islands and in coastal/shelf regions (e.g. Scotia Sea, Weddell Sea, Ross Sea; Arrigo et al., 1998; Moore and Abbott, 2000) and in the vicinity of the circumpolar receding ice edge (Arrigo et al., 1998; Fitch and Moore, 2007). All this suggests some iron limitation relief for phytoplankton growth.

Potential iron sources for Antarctic surface waters include transport of deep ocean waters - with possible enrichment due to contact with sediments and remineralization at depth - mineral dust deposition associated with continental (Jickells et al., 2005) and extraterrestrial (Johnson, 2001) inputs, sediment resuspension and lateral advection (Moore and Braucher, 2008), snow and sea-ice melting (Sedwick and Di Tullio, 1997; Lannuzel et al., 2008) and iceberg melting/calving (Smith et al., 2007). The role of sedimentary sources of iron for stimulating phytoplankton blooms has been demonstrated in some regions as the Kerguelen and Crozet Plateau (Blain et al., 2007; Pollard et al., 2007, 2009). High iron concentrations $\left(2-4 \mu \mathrm{mol} \mathrm{m}^{-3}\right)$ have also been reported in the Scotia Sea (Nolting et al., 1991) possibly resulting from sedimentary sources from the extended continental shelves of the Antarctic Peninsula and atmospheric input from the Patagonian desert. High near-surface Chl- $a$ was measured in the vicinity of free-drifting icebergs in the Weddell Sea and was related to the release of iron-related terrigenous material (Smith et al., 2007). The occurrence of phytoplankton blooms at the receding ice-edge can be explained by ice melting that both promotes water stratification (Smith and Nelson, 1985; Lancelot et al., 1991, 1993) and releases in the water column the iron accumulated in the seaice during winter (Sedwick and Di Tullio, 1997; Tagliabue and Arrigo, 2006). Iron concentration of more than one order of magnitude higher than in adjacent surface waters has been measured in first-year sea-ice (Lannuzel et al., 2007, 2008). Because iron continental and extraterrestrial sources have low magnitude at high latitudes (Lannuzel et al., 2007; Wagener et al., 2008), iron must be primarily supplied by the ocean. In agreement an iron budget constructed from sea ice observations performed off East Antarctica estimates that $90 \%$ of iron sequestered in sea ice in winter is of oceanic origin (Lannuzel et al., 2007).

Today, we do not know how the aforementioned mechanisms shape the geographical distribution of dissolved iron within the oceanic surface layer, neither how this affects phytoplankton blooms in the modern Southern Ocean. As a step in this direction, recent sensitivity tests with the OGCBM PISCES model (Tagliabue et al., 2008) concluded to the predominance of sedimentary over atmospheric iron sources in driving carbon export in the Southern Ocean (Tagliabue et al., 2009). A factor between 1.4 and 9 was found and varied regionally (Tagliabue et al., 2009). Yet neither the contribution of iceberg calving/melting nor the role of sea ice formation and melting in governing iron availability in the Southern Ocean were addressed by these authors. The objective of the present study is to consider all known iron sources and redistribution mechanisms to get new insight on iron distribution fields and related phytoplankton patterns using simulations performed with the three-dimensional (3-D) ice-oceanbiogeochemical model NEMO-LIM-SWAMCO, which domain covers the whole Southern Ocean. Because of large uncertainties in the magnitude of the iron sources, a precise, quantitative estimate is currently not feasible. However, assuming reasonable values for all the sources, it is possible to assess the effect of each iron source on the regional phytoplankton bloom distribution and estimate which one most likely drives the spatio-temporal changes in each sub-region of the Southern Ocean. In addition we test as possible process explaining phytoplankton blooms in some marginal ice zones, the capture of iron during sea ice formation in winter and the transport of iron-rich sea ice away from the continental shelf, releasing iron in the surface ocean far from coastal regions (Sedwick et al., 1999; Fitzwater et al., 2000; Grotti et al., 2005). This potentially efficient mechanism cannot be estimated from available observations and, to our knowledge, has never been investigated in models at the scale of the whole Southern Ocean.

\section{Methods}

\subsection{Model description}

The 3-D sea-ice-ocean biogeochemical model results of the coupling between the ocean-sea-ice model NEMOLIM (Nucleus for European Modelling of the Ocean Louvain-la-Neuve Ice Model), and an upgraded version of the SWAMCO4 (Sea WAter Microbial COmmunity model) model (Pasquer et al., 2005).

\subsubsection{The ice-ocean model NEMO-LIM}

NEMO-LIM is coupling an updated version (LIM2) of the sea-ice model developed by Fichefet and Morales Maqueda (1997) to the hydrostatic, primitive equation ocean model OPA9 (Océan PArallélisé, Madec, 2008), as described in Timmerman et al. (2005). OPA9 is a finite difference ocean general circulation model with a free surface and a non-linear equation of state in the Jackett and McDougall (1995)'s formulation. In this application, lateral mixing is performed along isopycnals for tracers and along horizontal surfaces for the momentum. Eddyinduced tracer advection is parameterized following Gent and McWilliams (1990). Vertical eddy diffusivity and viscosity coefficients are computed from a level-1.5 turbulence closure scheme based on a prognostic equation for the turbulent kinetic energy (Blanke and Delecluse, 1993). Double diffusive mixing (i.e. salt fingering and diffusive layering) is computed following Merryfield et al. (1999) and the effect of the wind driven Langmuir circulation on vertical mixing is represented using the parameterization of $\mathrm{Li}$ and Garett (1997). In locations where stratification is statically 
unstable, a value of $100 \mathrm{~m}^{2} \mathrm{~s}^{-1}$ is assigned to the vertical eddy coefficients for momentum and tracers. The bottom boundary layer scheme of Beckmann and Döscher (1997) ensures an improved representation of dense water spreading over topography in this geopotential-coordinate model.

The thermodynamic module of LIM2 is an improved version of the Semtner's (1976) three-layer model (one layer for snow and two layers for ice) for sensible heat storage and vertical heat conduction within snow and ice. Vertical and lateral sea ice growth/melt rates are obtained from energy budgets at the upper and lower surfaces of the snow-ice cover and at the surface of open water present within the ice pack. The snow or sea ice surface temperature is computed from the energy budget within the surface layer which thickness is $10 \mathrm{~cm}$ or less. The effect of the subgrid-scale snow and ice thickness distributions is accounted for through an effective thermal conductivity determined following Fichefet and Morales Maqueda (1997), which is computed by assuming that the snow and ice thicknesses are uniformly distributed between zero and twice their mean value over the ice-covered portion of the grid cell. Storage of latent heat inside the ice resulting from the trapping of shortwave radiation within brine pockets follows the approach of Semtner (1976). When the load of snow is large enough to depress the snow-ice interface under the water level, seawater is assumed to infiltrate the entirety of the submerged snow and to freeze there, forming a snow ice layer. The sea ice velocity field is determined from the momentum balance, assuming that sea ice is a two-dimensional continuum in dynamical interaction with atmosphere and ocean. The viscous-plastic constitutive law proposed by Hibler (1979) is used to compute the internal stresses within the ice for different states of deformation.

\subsubsection{The biogeochemical model SWAMCO}

Ocean biogeochemistry is represented by means of the complex SWAMCO model (Lancelot et al., 2000) modified as in Pasquer et al. (2005) for addition of two key phytoplankton functional groups (coccolithophorids and Phaeocystis colonies) and calibrated in a 1D physical frame. Basically the ecological module of SWAMCO integrates knowledge on mechanisms controlling biological productivity and the structure of the ocean planktonic ecosystem. In particular, it takes into account the key role of iron in driving the structure and functioning of the planktonic network and the related biogeochemical cycles of C, N, Si, P, Fe. State variables (Fig. 1 in Pasquer et al., 2005) include major nutrients $\left(\mathrm{NH}_{4}, \mathrm{NO}_{3}, \mathrm{DSi}, \mathrm{PO}_{4}\right)$ and dissolved iron (DFe). The phytoplankton assemblage is described by four functional groups (diatoms, pico/nano phytoplankton, coccolithophorids and Phaeocystis colonies) distinguished on the basis of their physiology (iron and major nutrient uptake kinetics, photosynthetic parameters, sinking rate) and mode of biological control (micro/meso zooplankton grazing, cell lysis). Limitation of phytoplankton growth by irradiance and nutrients is expressed by the product of two Michaelis-Menten kinetics accounting for the availability of firstly the carbon substrates and energy and secondly the most limiting nutrient corresponding to the nutrient that displays the lowest ambient concentration compared to the half-saturation constant for phytoplankton uptake. Conceptually, it can be inorganic $\mathrm{N}\left(\mathrm{NO}_{3}+\mathrm{NH}_{4}\right), \mathrm{DSi}, \mathrm{PO}_{4}$ or $\mathrm{DFe}$ and the selection is determined at each time step. Loss terms include sinking, grazing pressure and cell lysis. All cells undergo lysis, expressed as a temperature- and nutrient-dependent first order function of cell biomass. Diatoms, coccolithophorids cells and liths and disrupted senescent Phaeocystis colonies aggregate and sink to deeper layers while pico/nano phytoplankton cells owing to their low size are retained in the surface layer. Coccolithophorids and pico/nano phytoplankton, the latter with however a preference rate, are ingested by microzooplankton which growth processes and associated remineralization rates are explicitly described. In contrast, mesozooplankton grazing constitutes a closure term of the model and is described as a first-order loss function for diatom and microzooplankton biomass. The microbial loop includes organic matter with three classes of lability and bacteria. Bacterial degradation of organic matter is described by Michaelis-Menten kinetics. Dissolution of biogenic silica is described as a first-order kinetics and nitrification by a Michaelis-Menten equation (Pasquer et al., 2005). The equation also includes a term for considering the inhibition effect of light on the activity of nitrifying bacteria (Olson, 1981). Compared to other similar biogeochemical models (e.g. Tagliabue and Arrigo, 2006) the description of Fe cycling in the present version of SWAMCO simply includes $\mathrm{DFe}$ and $\mathrm{Fe}$ in all particles without explicit consideration of Fe ligands and scavenging. We assume that DFe is bioavailable and includes truly dissolved inorganic Fe as well as organically complexed $\mathrm{Fe}(<0.4 \mu \mathrm{m})$. This allows consideration of the forms involved in the process of Fe biological uptake and remineralization in the model equations. The lack of description of particle Fe scavenging in SWAMCO was based on their low significance at $\mathrm{DFe}<0.6 \mu \mathrm{mol} \mathrm{m}^{-3}$ typical of the Southern Ocean (Johnson et al., 1997; Boye et al., 2001).

For this application, some of the parameterizations of SWAMCO were adapted. This consisted of, first, adding a new term for iron-limitation of photosynthesis and second, an update of parameters describing the iron uptake kinetics and iron-to-carbon stoichiometry. Photosynthesis iron limitation is now calculated from the positive linear relationship between the optimal photosynthetic rate and DFe availability, as suggested in Greene et al. (1991). Based on Timmermans et al. (2004)'s laboratory-controlled experiments, the half-saturation constant for DFe assimilation by diatoms has been set to $0.6 \mu \mathrm{mol} \mathrm{m}{ }^{-3}$ based on the average size of polar diatoms. This constant is significantly higher than those chosen for the pico/nanophytoplankton and the coccolithophorids $\left(0.03 \mu \mathrm{mol} \mathrm{m}^{-3}\right.$; Pasquer et al., 2005) but lower 
than that assigned to Phaeocystis colonies $\left(1.5 \mu \mathrm{mol} \mathrm{m}^{-3}\right.$; Pasquer et al., 2005). We also revised the iron stoichiometry (Fe:C) based on recent measurements of elemental composition for phytoplankton species including diatoms, nanophytoplankton, and coccolithophorids (Ho et al., 2003; Twining et al., 2004). The measured iron stoichiometry being in close range for these three phytoplankton groups we therefore adopted a unique value of $0.04 \mathrm{mmolFe}: \mathrm{molC}$. Finally, we updated iron stoichiometric parameterisation of microzooplankton and bacteria, setting their $\mathrm{Fe}: \mathrm{C}$ respectively to 0.03 and 0.04 mmolFe:molC (Twining et al., 2004) and revised microzooplankton mortality rate, now set to $0.001 \mathrm{~h}^{-1}$.

Compared to Pasquer et al. (2005), the parameterization of over-wintering conditions has been optimized on the basis of new tests performed with the 1D-SWAMCO version applied in the seasonally ice-covered domain. In the present version, microorganisms enter the dormancy phase when the light level at surface corresponds to a solar heat flux lower than $5 \mathrm{Wm}^{-2}$ and Chl- $a$ concentration at surface is lower than $0.1 \mathrm{mg} \mathrm{m}^{-3}$. This parameterization was adjusted based on late-fall/early-winter observations of phytoplankton biomass and the ambient light.

\subsubsection{Iron sequestration in sea ice and release in the surface ocean}

Processes leading to iron accumulation in sea ice have not yet been studied experimentally in spite of well-established observations reporting concentrations of one order of magnitude higher than in the adjacent surface waters (Lannuzel et al., 2006, 2007, 2008; Aguilar-Islas et al., 2008). Vancoppenolle et al. (2009b) argue that this accumulation is due to a rapid iron capture operating in synergy with the convection of liquid saline brine within the lowermost, porous ice layer. On this basis and as a very first approach, iron sequestration in snow and ice is described here by adding DFe as an explicit state variable of the LIM2 sea ice model and considering vertical homogeneity. Snow and ice DFe are transported horizontally due to sea ice drift, using the same advection scheme as for other model state variables. Processes considered by the model are: direct deposition of iron from mineral dust in the upper snow layer, DFe transfer from the snow to the sea ice during snow ice formation and, transfer of DFe from the ocean to the ice, associated to ice formation (lateral and basal). When sea ice forms, DFe is pumped from the ocean model upper layer to the sea ice in order to ensure a maximum concentration of $16.5 \mu \mathrm{mol} \mathrm{DFe} \mathrm{m}{ }^{-3}$ in the forming ice layer. The latter value is determined based on iron records in winter Antarctic pack ice (Lannuzel et al., 2007). If the DFe simulated in the ocean upper layer is not sufficient for sustaining the ocean-ice transfer required to reach this concentration, the model assumes that all the DFe of this oceanic layer is transferred to the sea ice. When sea ice melts, the accumulated DFe is released to the ocean layer assuming that melt water has a concentration equal to the mean sea ice
Table 1. Annual iron sources (absolute values and percentage) for the Southern Ocean South of $60^{\circ} \mathrm{S}$.

\begin{tabular}{lcc}
\hline Source & $10^{9} \mathrm{~mol} \mathrm{Fe} \mathrm{yr}^{-1}$ & $\%$ total \\
\hline Dust & 0.014 & 3 \\
Sediment & 0.38 & 90 \\
Iceberg calving/melting & 0.028 & 7 \\
\hline Total input & 0.0422 & 100 \\
\hline
\end{tabular}

DFe. At the end of the time step, the DFe content in sea ice is the sum of (i) the DFe content of sea ice at the beginning of the time step, (ii) the DFe contents of new basal and snowice layers and (iii) the DFe loss associated to melting. In this way, the parameterization strictly conserves the mass of iron in the ice-ocean system and does not provide any artificial source or sink of iron.

\subsection{NEMO-LIM-SWAMCO simulations}

\subsubsection{Iron sources}

There are large uncertainties on the magnitude and spatial distribution of the different iron sources in the Southern Ocean. In this work we assume that iron sources are spatially distributed but constant in time. Table 1 shows the absolute and relative annual iron input from the different sources to the model domain south of latitude $60^{\circ} \mathrm{S}$.

Bioavailable iron from atmospheric origin depends on direct iron deposition from mineral dust and solubility in seawater. Both processes are largely uncertain. Several global distributions of dust deposition are available in the literature but show a wide range of values in the Southern Ocean (Fan et al., 2006; Mahowald et al., 2005; Luo et al., 2003; Ginoux et al., 2001; Tegen and Fung; 1995, and Duce and Tindale, 1991). Among these, some give estimation for the associated iron deposition while, for some others, iron content in dust has to be estimated to reconstruct iron deposition fields. In addition, the percentage of dissolvable iron of dust origin is also reported to greatly vary (between $0.01 \%$ and $80 \%$; Mahowald et al., 2005), bringing an additional uncertainty of the same order of magnitude as that linked to iron deposition. Actual global ocean biogeochemical models encompass these uncertainties by assuming constant values of dust-iron solubility, with typical values of $1 \%$ (e.g. Parekh et al., 2005; Gregg et al., 2003; Aumont et al., 2003) or 2\% (e.g. Fung et al., 2000; Moore et al., 2004, Aumont and Bopp, 2006). In the present application, the iron atmospheric input is calculated from the estimation of global dust deposition of Mahowald et al. (2005), assuming a dust iron content of $3.5 \%$ and a solubility of $2 \%$ in order to impose an iron deposition that is approximately in the middle of the uncertainty range. The obtained geographical distribution in the NEMO-LIM-SWAMCO 

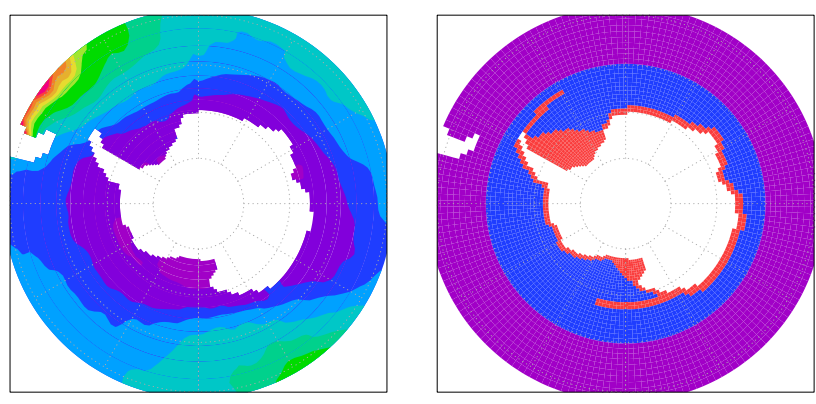

(a)

(b)

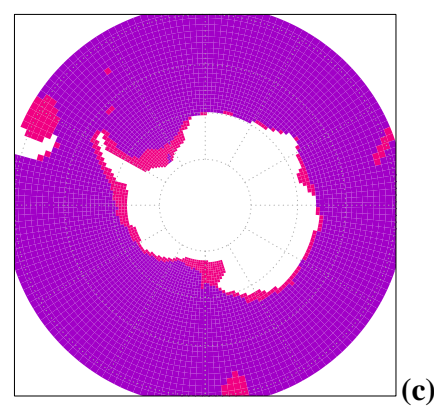

Fig. 1. Distribution of Fe sources ( $\mathrm{pmol} \mathrm{Fe} \mathrm{m}^{-2} \mathrm{~s}^{-1}$ ) in the model domain. (a) Atmospheric inputs; (b) iceberg calving/melting; (c) sediments. The fluxes from icebergs melting amount to $0.22 \mathrm{pmol} \mathrm{Fe} \mathrm{m}^{-2} \mathrm{~s}^{-1}$ close to the continent (in red) and to $0.2210^{-2} \mathrm{pmol} \mathrm{Fe} \mathrm{m}^{-2} \mathrm{~s}^{-1}$ further to the north (in blue). The sediment fluxes are equal to $5 \mathrm{pmol} \mathrm{Fe} \mathrm{m} \mathrm{m}^{-2} \mathrm{~s}^{-1}$ (in purple). Note that the color scale is not linear.

domain (Fig. 1a) shows a clear decrease of bioavailable iron deposition towards high latitudes. The minimum values are found around Antarctica with inputs lower than $0.01 \mathrm{pmol} \mathrm{Fe} \mathrm{m}^{-2} \mathrm{~s}^{-1}\left(\sim 8.610^{-4} \mu \mathrm{mol} \mathrm{Fe} \mathrm{m}^{-2} \mathrm{~d}^{-1}\right)$, except near the Peninsula where inputs reach $0.3 \mathrm{pmol} \mathrm{Fe} \mathrm{m}^{-2} \mathrm{~s}^{-1}$ $\left(\sim 0.026 \mu \mathrm{mol} \mathrm{Fe} \mathrm{m}^{-2} \mathrm{~d}^{-1}\right)$. By contrast, the highest values are found in the south Atlantic, close to the southern tip of America with values around $0.5 \mathrm{pmol} \mathrm{Fe} \mathrm{m}^{-2} \mathrm{~s}^{-1}$ $\left(\sim 0.043 \mu \mathrm{molFe} \mathrm{m}^{-2} \mathrm{~d}^{-1}\right)$, because of the proximity of Patagonia.

The iron supply from melting icebergs is calculated by combining estimates of calving with sediment loads in icebergs. While reasonable estimates of total iceberg calving from Antarctica do exist, only a few measurements of the iron concentration in icebergs have been performed. Here, it is assumed that iceberg calving exports $2 \mathrm{Tm}^{3} \mathrm{yr}^{-1}$ of ice into the Southern Ocean waters (Church et al., 2001) and that iron concentration in glacial ice is $20.4 \mu \mathrm{mol} \mathrm{Fe} \mathrm{m}^{-3}$ (Löscher et al., 1997). The spatial distribution of icebergderived iron supply is based on the results of an iceberg model (Gladstone et al., 2001), which computes the spatial distribution of the melt water injected into the ocean due to iceberg melting. The resulting geographical distribution of iceberg-derived iron is highly contrasted (Fig. 1b). The iron input pattern mimics the iceberg migration with high release of $0.22 \mathrm{pmol} \mathrm{Fe} \mathrm{m}^{-2} \mathrm{~s}^{-1}\left(0.019 \mu \mathrm{mol} \mathrm{Fe} \mathrm{m}^{-2} \mathrm{~d}^{-1}\right)$ near Antarctica, in the vicinity of the continental shelves of the Weddell and Ross seas, as well as in northern limbs of the Weddell and Ross gyres. By contrast, out of those regions, the iron release is two orders of magnitude lower and nil beyond $60^{\circ} \mathrm{S}$. Our estimate is one order of magnitude lower than the recent estimate of bioavailable iron supplied to the Southern Ocean from icebergs $\left(0.14-0.28 \mu \mathrm{mol} \mathrm{Fe} \mathrm{m}^{-2} \mathrm{~d}^{-1}\right.$; Raiswell et al., 2008) but compares better with the low DFe concentrations observed in the present-day Southern Ocean. The difference between our estimate and that by Raiswell et al. (2008) is due to the fact that the latter includes nanoparticulate $\mathrm{Fe}$ oxyhydroxides from ice-hosted sediment corrected for their bioavailability. However once release in the water column the major part of these nanoparticles will likely be quickly exported to the deep ocean, hence being not significant for the surface layer, our domain of investigation.

The few estimates of iron supply from sediments cover a wide range, from $1.2 \mathrm{pmol} \mathrm{Fe} \mathrm{m}^{-2} \mathrm{~s}^{-1}\left(0.1 \mu \mathrm{mol} \mathrm{Fe} \mathrm{m}^{-2} \mathrm{~d}^{-1}\right)$ for the Kergelen plateau (Blain et al., 2007) to $50 \mathrm{pmol} \mathrm{Fe} \mathrm{m}^{-2} \mathrm{~s}^{-1} \quad\left(4.3 \mu \mathrm{mol} \mathrm{Fe} \mathrm{m} \mathrm{m}^{-2} \mathrm{~d}^{-1}\right)$, an averaged value for the continental shelves at global scale (Elrod et al., 2004). In global ocean biogeochemical models, iron from sedimentary sources has been incorporated in different ways (e.g. Moore et al., 2004; Moore and Braucher, 2008; Aumont and Bopp, 2006). Moore et al. (2004) used a constant value of $23 \mathrm{pmol} \mathrm{Fe} \mathrm{m}^{-2} \mathrm{~s}^{-1}\left(2 \mu \mathrm{mol} \mathrm{Fe} \mathrm{m}^{-2} \mathrm{~d}^{-1}\right)$ in all model grid points shallower than $1100 \mathrm{~m}$. Aumont and Bopp (2006) assumed a maximum iron source from sediments of $16 \mathrm{pmol} \mathrm{Fe} \mathrm{m}^{-2} \mathrm{~s}^{-1}\left(1 \mu \mathrm{mol} \mathrm{Fe} \mathrm{m}{ }^{-2} \mathrm{~d}^{-1}\right)$, which is modulated by a factor indicating how well the sediment is oxygenated. Finally, Moore and Braucher (2008) have developed a more realistic distribution based on a high-resolution bathymetry and an estimate of the Fe flux constrained by the carbon export. In their model, the sediment fluxes reach $1.5810^{-6} \mu \mathrm{mol} \mathrm{Fe} \mathrm{m}^{-2} \mathrm{~s}^{-1} \quad\left(0.14 \mu \mathrm{mol} \mathrm{Fe} \mathrm{m}^{-2} \mathrm{~d}^{-1}\right)$ in the vicinity of the Antarctic continent (Fig. 2 in Moore and Braucher, 2008). For our application we choose to impose a source of DFe of $5 \mathrm{pmol} \mathrm{Fe} \mathrm{m}^{-2} \mathrm{~s}^{-1}\left(0.43 \mu \mathrm{mol} \mathrm{Fe} \mathrm{m}^{-2} \mathrm{~d}^{-1}\right)$ in all the model grid points shallower than $900 \mathrm{~m}$ (Fig. 1c). This flux was calculated combining a $\mathrm{Kz}$ estimate of $1 \times 10^{-4} \mathrm{~m}^{2} \mathrm{~s}^{-1}$ as a mean value for the Southern Ocean (Law et al., 2003; Blain et al., 2007) with DFe gradients from a deep vertical profile of DFe measured in the Scotia Sea with input from the continental shelf of the Orkneys Islands (de Jong et al., 2009). This is an apparent flux from the continental shelf that takes into account the direct input of DFe from the sediments and also the input of DFe released from the dissolution of particulate lithogenic Fe. No sediment flux is considered for grid points deeper than $900 \mathrm{~m}$, as values are much lower there and the Fe released at great depths will not reach the surface at the time scale of our simulations. 


\subsubsection{Model configuration}

The fully coupled NEMO-LIM-SWAMCO model is implemented in the ocean domain south of $30^{\circ} \mathrm{S}$ with a resolution of $2^{\circ}$ in longitude and in latitude $2^{\circ}$ times the cosine of the latitude (i.e. about $50 \mathrm{~km}$ close to the Antarctic continent; Madec et al., 1999). Thirty vertical ocean levels are used, among which 10 are located in the upper $100 \mathrm{~m}$. Temperature, salinity and meridional velocity at the northern open boundary at $30^{\circ} \mathrm{S}$ were obtained based on a simulation performed with the global version of NEMO-LIM, averaged over 1979-2002. For $\mathrm{NO}_{3}, \mathrm{NH}_{4}, \mathrm{PO}_{4}$, DSi, DIC and alkalinity, the values prescribed at the northern boundary are retrieved from the climatology of Levitus (1998). The DFe vertical profile used as initial condition (see below) is also applied at the boundary. Exchanges across the open boundary for all the aforementioned variables were estimated through a combination of radiation conditions and relaxation towards climatology (Molines et al., 2003), as described in Mathiot (2009). For the other biogeochemical variables, no large-scale information is available and a zero flux across the open boundary was assumed. Preliminary tests showed that this method produces results that are nearly identical to those obtained with the global version of the model (de Montety, 2006).

Initial conditions for temperature, salinity and meridional velocity were determined on basis of an 85 -yr simulation performed with the global NEMO-LIM model using an interannual forcing, as described in Timmermann et al. (2005). Initial concentrations of $\mathrm{NO}_{3}, \mathrm{NH}_{4}, \mathrm{PO}_{4}, \mathrm{DSi}$, DIC and alkalinity are derived from the Levitus climatology (1998). For DFe, the vertical profile obtained by Moore and Braucher (2008) by averaging all the available data in the Southern Ocean (Fig. 2) is imposed in the whole domain, except for grid points shallower than $600 \mathrm{~m}$, where a constant value of $1 \mu \mathrm{mol} \mathrm{Fe} \mathrm{m}{ }^{-3}$ is assumed to better take into account observations. DFe in sea ice and snow is initially set to a value of $16.5 \mu \mathrm{mol} \mathrm{Fe} \mathrm{m}{ }^{-3}$, which is assumed to be reached when sea ice forms if enough DFe is available in the surface ocean. The remaining biogeochemical variables are initially set to a constant value retrieved from published observations.

\subsubsection{Forcing}

Model simulations were run from September 1989 to December 2000 using daily 2-m air temperatures and 10-m winds from the NCEP/NCAR reanalysis project (Kalnay et al., 1996), and monthly climatologies of surface relative humidity (Trenberth et al., 1989), cloud fraction (Berliand and Strokina, 1980), and precipitation rate (Xie and Arkin, 1996). Surface fluxes of heat and moisture are estimated from these data, using empirical parameterizations (Goosse, 1997). Evaporation/sublimation is derived from the turbulent flux of latent heat. In addition, the surface salinity of

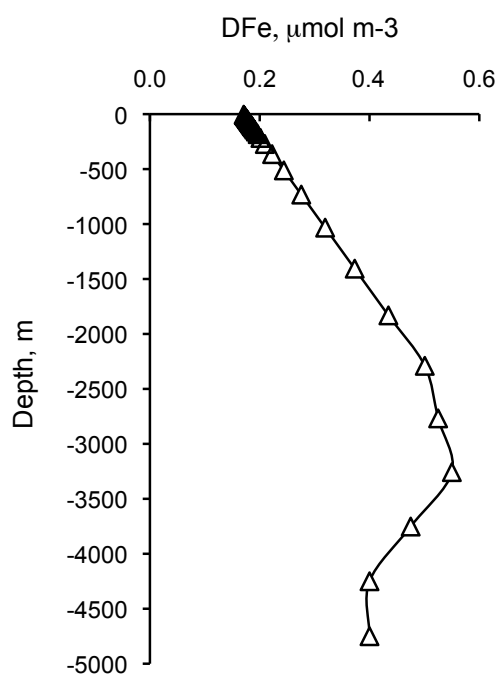

Fig. 2. Vertical profile of dissolved iron $\left(\mu \mathrm{mol} \mathrm{Fe} \mathrm{m}^{-3}\right)$ used as initial condition for the whole Southern Ocean simulations. Redrawn from Moore and Braucher (2008).

the ocean is restored towards the climatology of Levitus with a relaxation timescale of 2 months. This restoring is required because precipitation is not very precise in the Southern Ocean and without such a restoring surface salinity will drift quickly away from observations. The momentum fluxes at the interfaces are obtained from standard bulk formulae. Incident PAR is estimated from global solar irradiance using the conversion factor measured by Lancelot et al. (1991). The decrease of PAR in the water column depends on the computed Chl- $a$ according to a Beer-Lambert law, parameterized for Antarctic waters (Lancelot et al., 1991).

\subsubsection{Numerical experiments}

Five 11-yr simulations (Table 2) were conducted with the fully coupled NEMO-LIM-SWAMCO model from September 1989 to December 2000. Here, results of the simulation are analyzed over the period 1997-2000 only, the first 8 years being considered as a spin up during which near-surface values reach a quasi-equilibrium state. The latter was checked for the nominal run by performing an additional 11-yr simulation initiated in 1989 with conditions obtained in 2000. No significant difference was obtained between the two simulations in the surface layers for the 1997-2000 period indicating that the drift in the 11-yr run was much smaller than the analyzed signal, which corresponds to a practical definition of quasi-equilibrium. More specifically, the model drift in the surface waters was on average $0.001 \mu \mathrm{mol} \mathrm{Fe} \mathrm{m}{ }^{-3} \mathrm{yr}^{-1}$ for the simulated period i.e. much less than the variations of the analyzed biogeochemical features. The nominal simulation (FULL) is obtained when applying in NEMO-LIMSWAMCO all the iron sources described in Sect. 2.2.1 (atmospheric, iceberg melting and sedimentary inputs) and 
Table 2. Description of NEMO-LIM-SWAMCO scenarios.

\begin{tabular}{llc}
\hline Scenarios & Iron sources & $\begin{array}{c}\text { Iron sequestration } \\
\text { in ice }\end{array}$ \\
\hline FULL & $\begin{array}{l}\text { Atmospheric+sedimentary+ } \\
\text { iceberg melting } \\
\text { sedimentary+iceberg } \\
\text { melting }\end{array}$ & Yes \\
NOatm & Yes \\
NOicb & $\begin{array}{l}\text { Atmospheric+sedimentary } \\
\text { Atmospheric +iceberg } \\
\text { melting }\end{array}$ & Yes \\
NOice & $\begin{array}{l}\text { Atmospheric+sedimentary+ } \\
\text { iceberg melting }\end{array}$ & Yes \\
& & No \\
\hline
\end{tabular}

activating the mechanism of sea-ice iron sequestration and release in the ocean surface layer. The contribution of each iron source to the model results is discussed by comparing the nominal simulation with sensitivity experiments in which one iron source or the mechanism of sea-ice iron sequestration and release in the surface layer is switched off.

\section{Model results}

\subsection{Physical constrains}

The features of the sea ice and ocean simulated by the present model resemble the simulation results of an earlier version (referred to as ORCA-LIM in Timmermann et al., 2005). Details on the model's ability to reproduce the mean state of the ice-ocean system and the observed interannual variability of the sea-ice extent, in particular in the Southern Ocean, can be found in Timmermann et al. (2004, 2005), Lefebvre et al. (2004) and Lefebvre and Goosse $(2005,2008)$. Here a special attention is given to the model performance in simulating ice concentration and mixed layer depths, considering their constrain on light availability in the upper ocean.

The seasonal evolution of the sea-ice edge (Fig. 3) is reasonably well simulated by the model when compared to satellite observations. The main discrepancy is the summer underestimation of ice concentration by the model, in particular in the Western Weddell Sea along the Antarctic Peninsula (Fig. 3a). In addition, the simulated ice thickness is smaller than observed all year long in this region (Timmerman et al., 2004, 2005). This is a general weakness shown by many models (Griffies et al., 2009; Timmerman et al., 2002, 2004; Mathiot, 2009), which has been attributed, at least partly, to the poor representation of the influence of the Antarctic Peninsula in the forcing (Vancoppenolle et al., 2009a; Mathiot 2009). Furthermore, the model fails to simulate sea ice in summer along the coasts of the Indian and Pacific sectors (Fig. 3a). This is due to the coarse resolution, preventing the representation of the coastal narrow strip, which is ice-covered all year long. The summer Ross sea

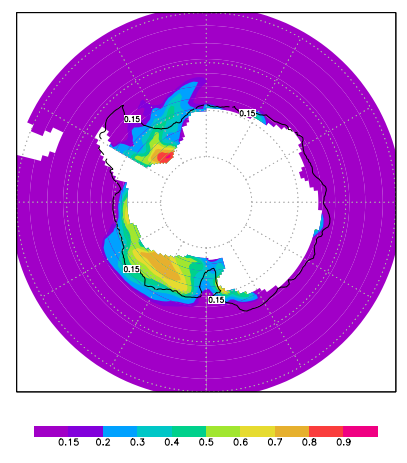

(a)

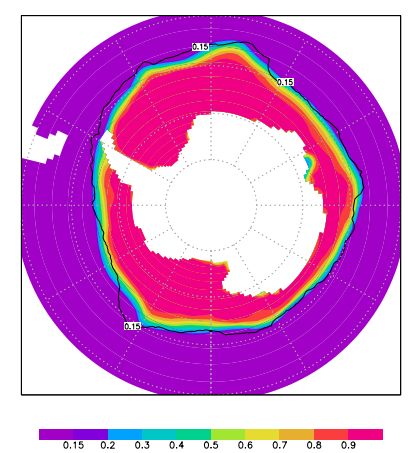

(b)
Fig. 3. Simulated sea-ice average concentration (fraction) for (a) summer (January-February-March) and (b) winter (July-AugustSeptember) for the period 1997-2000. The sea-ice extent from the HadISST dataset (15\% ice cover location; Rayner et al., 2003 and updates) is added in black contour for the same period.

polynya opens a bit too late in the model, explaining the simulated overestimations of ice concentration from January to March (Fig. 3a). By contrast, the maximum ice extent in winter is very well simulated (Fig. 3b), with minor departure from observation. As discussed in Timmermann et al. (2004, 2005), the simulated ice thickness agrees with observations, except along the coasts, in particular in the Weddell Sea. The sea-ice drift is also well described by the model, with simulated ice velocities that reproduce both qualitative and quantitative estimates based on satellite measurements (Timmermann et al., 2005).

The simulated mixed layer depth (MLD) shows several circumpolar maxima in the $40^{\circ}-60^{\circ} \mathrm{S}$ latitude band (Fig. 4ab), in agreement with the climatology established by de Boyer Montégut et al. (2004). In this region, the maximal MLD reaches 90 and $250 \mathrm{~m}$ in summer (Fig. 4a) and winter (Fig. 4b) respectively. The MLD appears noisier in the observations (Fig. 4c-d) than in the model (Fig. 4a-b), probably due to under-sampling in the observations. Nevertheless, the position and magnitude of the local MLD maxima are well simulated for all basins but in the South Atlantic. South of the $60^{\circ} \mathrm{S}$, the MLD is comparatively shallow both in model and observations. In addition, around Antarctica, in winter, there are several coastal areas with high MLD. Because there are only a few MLD observations below the ice, those features are absent from the climatology of de Boyer Montégut et al. (2004), except in the eastern Weddell Sea. In summer, the climatology suggests much higher MLD values than the model simulation in the western Weddell Sea and close to the coast around $135^{\circ} \mathrm{W}$. However, one should bear in mind that those regions are sea-ice covered nearly every year (Fig. 4c) and hence are highly under-sampled in the climatology. 

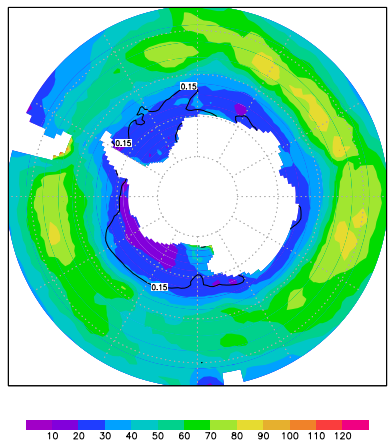

(a)
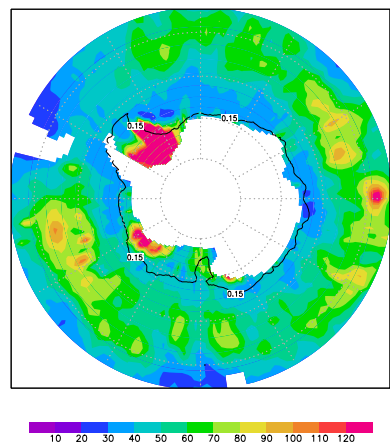

(c)
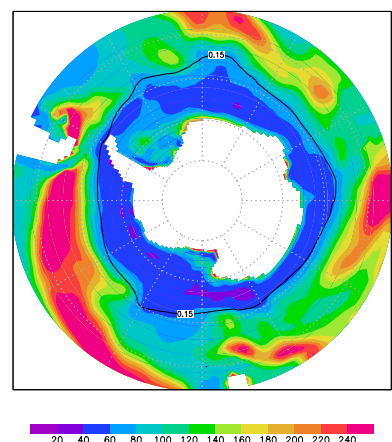

(b)

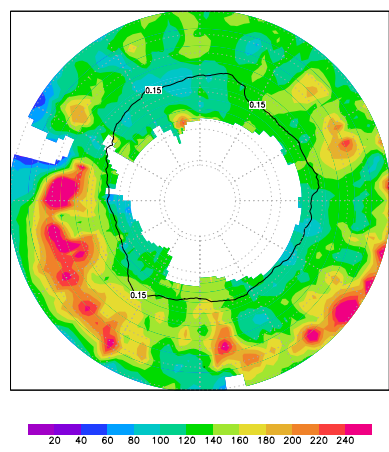

(d)
Fig. 4. Simulated MLD (m) for the period 1997-2000 (upper panels) compared to the global climatology of de Boyer Montégut et al. (2004) (lower panels) averaged for (a, c) summer (JanuaryFebruary-March) and (b, d) winter (July-August-September). The modeled (upper panels) and climatological (HadISST, Rayner et al., 2003 and updates; lower panels) sea-ice extent are also displayed in contour for both seasons.

\subsection{Distributions of ocean (surface and depth) and sea-ice DFe}

The global ability of the NEMO-LIM-SWAMCO model to simulate DFe distributions in the Southern Ocean can be appraised from Fig. 5 that compares monthly model DFe averaged for the 1997-2000 period with available observations (Moore and Braucher, 2008) interpolated on the model grid. Examination of Fig. 5 that includes a total of 574 data pairs shows a fairly good correspondence between observations and simulations (correlation coefficient: 0.41, root mean square error: $0.14 \mu \mathrm{mol} \mathrm{Fe} \mathrm{m}^{-3}$ ). As shown on Fig. 5, departure from the 1:1 slope is due to coastal stations characterized by elevated near-surface DFe, which is not resolved by the vertical grid of the model. Discarding these coastal stations improve the correspondence level between simulations and observations (correlation coefficient: 0.55 , root mean square error: $\left.0.12 \mu \mathrm{mol} \mathrm{Fe} \mathrm{m}{ }^{-3} ; n=541\right)$ and hence the confidence level in our model results. An additional statistical test conducted on the first $500 \mathrm{~m}$ i.e. where biogeochemical changes are sensitive during the 11-yr simulated period

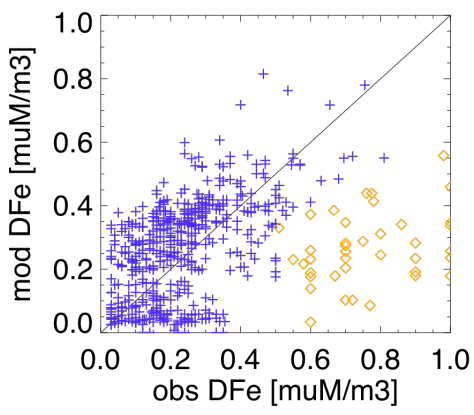

Fig. 5. Comparison between Southern Ocean DFe measurements (Moore and Braucher, 2008) and 1997-2000 monthy average model output at the same month, location and depth of observations. Yellow diamonds refer to coastal stations with elevated near-surface DFe.

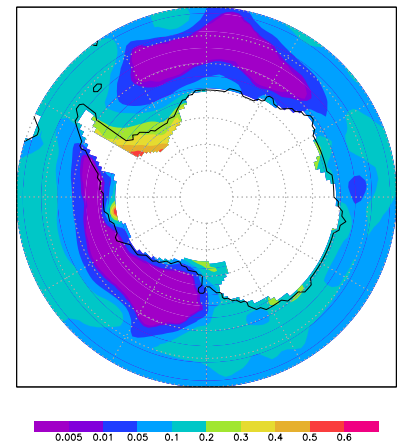

(a)

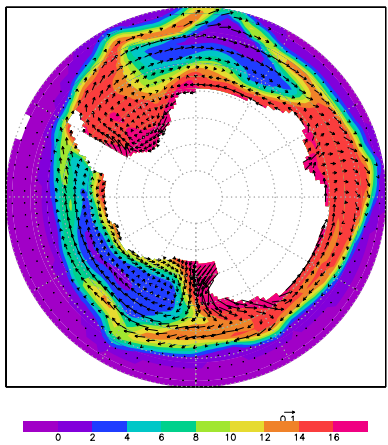

(b)
Fig. 6. Simulated DFe $\left(\mu \mathrm{mol} \mathrm{Fe} \mathrm{m}^{-3}\right)$ in (a) surface waters and (b) sea ice, averaged in winter (July-August-September) for the 19972000 period. The contour line corresponds to the $1200 \mathrm{~m}$ isobath. Note that the color scale is not linear.

confirms the good correspondence between simulations and observations (correlation coefficient: 0.37 , root mean square error: $0.12 \mu \mathrm{mol} \mathrm{Fe} \mathrm{m}^{-3} ; n=446$ )

The simulated surface oceanic DFe fields show a seasonal cycle characterized by large-amplitude variations. During austral summer, the simulated DFe is extremely low in surface waters due to a fast biological uptake (not shown). The highest surface DFe concentrations are simulated in winter (Fig. 6a) due to DFe remineralisation by heterotrophic processes and to the deepening of the upper mixed layer when surface waters are merging with iron-rich waters from depth. Examination of Fig. 6a reveals a clear contrast between winter DFe of coastal and deep ocean regions. For instance, $\mathrm{DFe}>0.5 \mu \mathrm{mol} \mathrm{Fe} \mathrm{m}^{-3}$ are simulated in the Weddell Sea while concentrations $<0.2 \mu \mathrm{mol} \mathrm{Fe} \mathrm{m}^{-3}$ are suggested offshore (Fig. 6).

Figure 7 compares modelled and observed (Moore and Braucher, 2008) mean annual DFe vertical profiles for two regions: "shallow" (or "shelf") and "deep" as constructed based on all available DFe vertical profiles. The complete validation set of vertical profiles is available 
as supplementary material (http://www.biogeosciences.net/ 6/2861/2009/bg-6-2861-2009-supplement.pdf) of this article. Following this classification, "shallow" ("deep") regions gather all the model grid points characterized by water depths shallower (deeper) than $1200 \mathrm{~m}$. The comparison indicates that the model is able to reproduce the $\mathrm{DFe}$ excess observed below the surface layer in shallow regions compared to deep regions (Fig. 7). At $500 \mathrm{~m}$ depth, first, the simulated mean values of $0.7 \mu \mathrm{mol} \mathrm{Fe} \mathrm{m}^{-3}$ on the shelf and of $0.4 \mu \mathrm{mol} \mathrm{Fe} \mathrm{m}^{-3}$ off shore are in reasonable agreement with estimates derived from observations (Fig. 7). In the deep regions, the model reproduces almost perfectly the vertical profile reconstructed from observations (Fig. 7a). It has however to be pointed that below $500 \mathrm{~m}$, the excellent simulated DFe levels can be partly explained by the use of realistic initial conditions (Fig. 2) that have only been slightly modified since the beginning of the simulation run. However, in the upper ocean, where changes are faster, the good agreement between simulated and observed DFe (Fig. 7a) indicates that the model is stable and provides results consistent with observations when using the selected iron sources. Second, over the continental shelves, the model also well reproduces the observed vertical profile, except near the surface where values up to $1 \mu \mathrm{mol} \mathrm{Fe} \mathrm{m}^{-3}$ or higher are reported (Fig. 7b). Such elevated values are very localized and transient (e.g. Sedwick and Di Tullio, 1997) and might not be resolved by the model. This failure may also reflect model overestimation of iron capture in some coastal sea-ice as well as some missing local effects (in particular near the coasts) or strong localized iron inputs that are not taken into account in the actual model.

Another remarkable feature of model simulations is the strong regional variability of DFe in surface waters in winter. Interestingly, the deep ocean off the shelves of the Bellingshausen and Amundsen seas as well as the Atlantic-Indian sector are characterized by extremely low DFe concentrations $\left(<0.05 \mu \mathrm{mol} \mathrm{Fe} \mathrm{m}^{-3}\right.$; Fig. 6a). Nearly no observation is available in those regions during the austral winter. However, some information on surface concentration in winter can be obtained by analysing the DFe values recorded at the base of the upper mixed layer (around $200 \mathrm{~m}$ ) during spring and summer. At this depth, low DFe values of 0.1 to $0.2 \mu \mathrm{mol} \mathrm{Fe} \mathrm{m}^{-3}$ have been observed in many locations around Antarctica: in the Weddell sector (Boye et al., 2001; Croot et al., 2004; de Jong et al., 1998), in the Western Pacific Ocean sector (Sohrin et al.; 2000; Sedwick et al., 1999), in the Ross Sea sector (Coale et al., 2005) and in the Bellingshausen-Amundsen Seas (de Baar et al., 1999). However, only a few extremely low values $\left(\sim 0.05 \mu \mathrm{mol} \mathrm{Fe} \mathrm{m}^{-3}\right)$ have been recorded (Croot et al., 2004; Coale et al., 2005), suggesting that the simulated $\mathrm{DFe}$ in these two regions is underestimated. This underestimation most likely results from the simple parameterization used to describe the transfer of ocean DFe to sea ice. When sea ice forms, DFe is indeed taken up from the ocean surface independently of
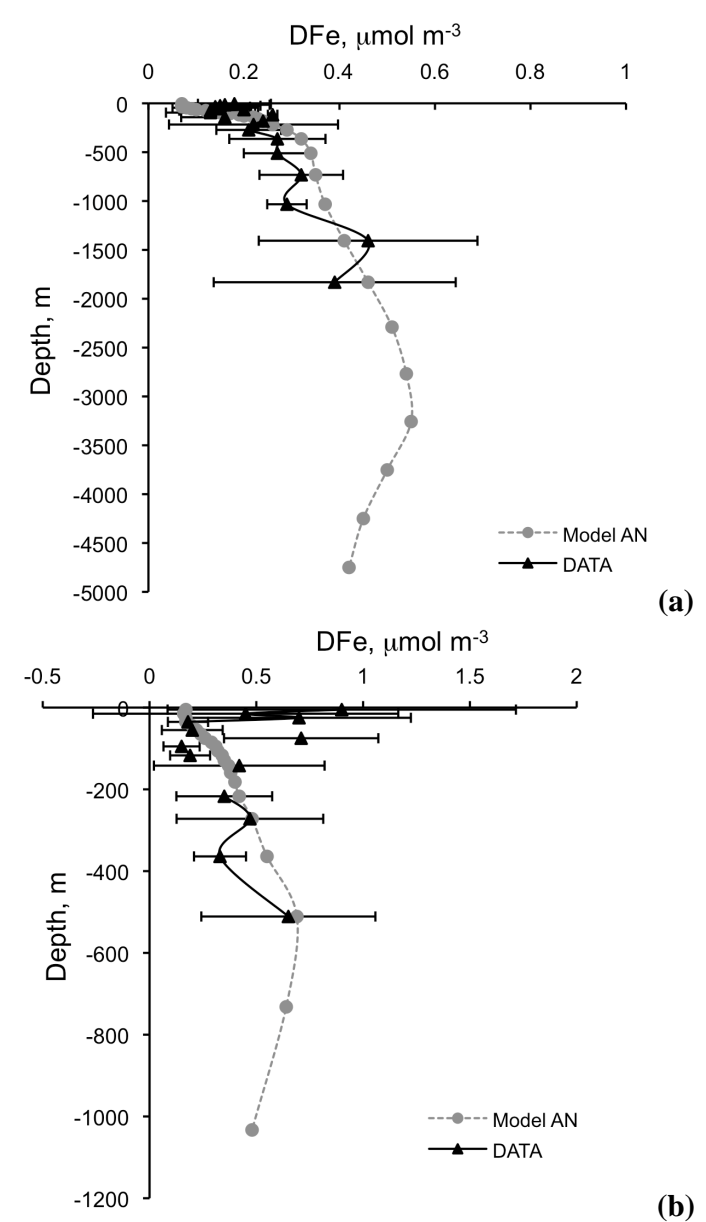

(a)

Fig. 7. Simulated and observed (reconstructed from Moore and Braucher, 2008) vertical DFe profiles $\left(\mu \mathrm{mol} \mathrm{Fe} \mathrm{m}^{-3}\right)$ for (a) "deep" (depth $>1200 \mathrm{~m}$ ) and (b) "shallow" (depth $<1200 \mathrm{~m})$ regions of the Southern Ocean (South of $60^{\circ} \mathrm{S}$ ). Horizontal bars show the data standard deviations.

its value. In area where the simulated concentration is too low, nearly all the DFe contained in the upper layer is incorporated in the ice, leaving DFe values close to zero at the ocean surface. In agreement, the simulated $\mathrm{Fe}$ accumulation in sea-ice (Fig. 6b) reflects surface water Fe concentrations in winter when ice cover is at maximum (Fig. 6a). Regions characterized by very low DFe concentrations in the ocean (Fig. 6a) are associated with simulated low iron concentration in sea ice $\left(<6 \mu \mathrm{mol} \mathrm{Fe} \mathrm{m}^{-3}\right.$; Fig. $\left.6 \mathrm{~b}\right)$. This is in accordance with the average DFe concentrations recently measured in the Bellinghsausen Sea $\left(4.83 \pm 5.12 \mu \mathrm{mol} \mathrm{Fe} \mathrm{m}^{-3}\right.$; Masson et al., 2009). The highest DFe concentrations in sea ice are simulated in the continental shelves (Fig. 6b), where the modelled surface ocean DFe is high enough to sustain ocean-to-ice iron fluxes during ice growth that are close to the maximum $\left(16.5 \mu \mathrm{mol} \mathrm{Fe} \mathrm{m}^{-3}\right)$. In agreement with this, elevated mean iron sea-ice concentrations of 1218 and $14.8 \mu \mathrm{mol} \mathrm{Fe} \mathrm{m}^{-3}$ have been measured in winter in 
respectively the East Antarctic (Lannuzel et al., 2007) and Weddell Sea (Lannuzel et al., 2008) pack ice. However lower DFe mean concentrations $\left(2.12-5.78 \mu \mathrm{mol} \mathrm{Fe} \mathrm{m}^{-3}\right)$ were reported in coastal sea ice of Terra Nova Bay (Ross Sea; Grotti et al., 2005).

\subsection{Phytoplankton bloom magnitude and extent}

The model distribution of surface Chl- $a$ in Spring (December) and Summer (February) for the years 1997-2000 corresponds reasonably well to SeaWiFS-derived observations for the same period (Fig. 8). As generally observed in the Southern Ocean (Fitch and Moore, 2007; Arrigo et al., 2008), the highest simulated surface Chl- $a$ concentrations ( $>2.5 \mathrm{mg} \mathrm{m}^{-3}$ ) are obtained close to the receding ice-edge and on the continental shelves, mainly off East Antarctica, in the Ross Sea and in the western Weddell Sea. By contrast, the Chl- $a$ concentration is extremely low $\left(<0.1 \mathrm{mg} \mathrm{m}^{-3}\right)$ both in observations and simulations in the BellingshausenAmundsen Seas and in the eastern Weddell Sea. A comparison with the winter distribution of surface and sea-ice DFe (Fig. 6) suggests that in these regions in other respect characterized by shallow MLD in summer (Fig. 4a), low iron availability rather than light is limiting the phytoplankton growth in spring and summer (Fig. 8). As a consequence of the dominant iron limitation, the observed and simulated circumpolar asymmetry of summer surface Chl- $a$ (Fig. 8) mimics that shown by the simulated DFe distribution field in winter (Fig. 6).

Nevertheless, in spite of missing SeaWIFS data due to clouds, the spatial extent of the bloom predicted by the model is larger than observed, leading in many areas to simulated surface Chl- $a$ higher than observed (Fig. 8). Such an overestimation of Chl- $a$ in the Southern Ocean is shown in many models (see for example Fig. 3 in Moore et al., 2004; Fig. 3 in Aumont and Bopp, 2006; Fig. 9b in Dutkiewicz et al., 2005). The bias has been attributed to several factors such as an unrealistic trapping of nutrients in the surface layer in models (Dutkiewicz et al., 2005) or an underestimation of in situ observed Chl- $a$ by SeaWiFS-derived data (this underestimation can reach up to a factor of 3 in some regions according to Preunkert et al., 2007). In our model, limitation in some process description like the absence of krill grazing pressure might well explain the too elevated surface Chl- $a$ predicted in e.g. the West Antarctic Peninsula ScotiaWeddell Sea and East Antarctica where significant swarms are commonly reported (Atkinson et al., 2004). Moreover the similar geographical patterns obtained for sea ice DFe in winter (Fig. 6b) and the corresponding surface Chl- $a$ in spring/summer (Fig. 8) suggest that the chosen parameterization for iron capture in sea-ice determines the position and spatial extent of regions of the marginal ice zone with very high or very low Chl- $a$ and hence explains the little discrepancy between the modeled and observed areas of high and low Chl- $a$ (Fig. 8). Furthermore, the model results
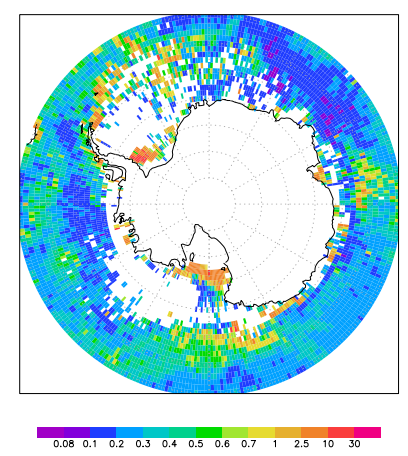

(a)
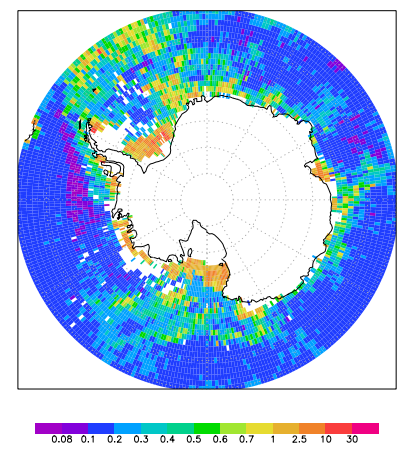

(c)
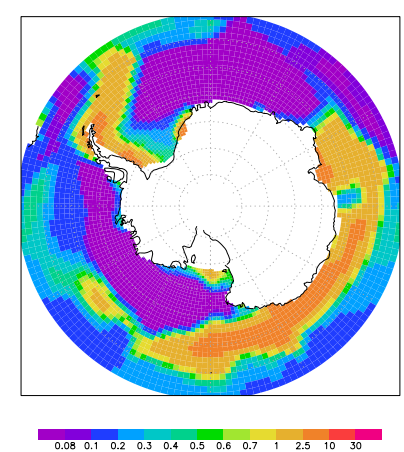

(b)

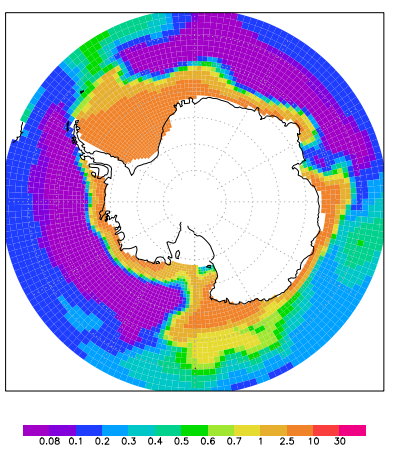

(d)
Fig. 8. SeaWIFS-derived (Acker and Leptoukh, 2007) and simulated surface Chl- $a\left(\mathrm{mg} \mathrm{m}^{-3}\right)$ averaged for (a-b) Spring (December) and (c-d) Summer (February) over the 1997-2000 period. Note that the color scale is not linear.

tend to be spatially more homogenous than in the SeaWiFSderived Chl- $a$, in regions characterized by both high and low phytoplankton concentration. This lack of spatial heterogeneity in our simulation might be due to the relatively low model resolution, which does not allow resolving structures such as fronts or the local influence of topography which is associated with excessive diffusion.

\section{Discussion}

The influence of the iron accumulation process in sea ice and release after melting and the contribution of the different iron sources to the simulated complex geographical pattern of surface DFe and Chl- $a$ is discussed based on model sensitivity tests obtained by turning off separately each iron source or process (Table 2). A first-order estimate of the contribution of each mechanism is then obtained by computing the difference between the FULL experiment and the corresponding sensitivity experiment (Fig.9-10). Hence, the non-linear interactions between the different mechanisms are not considered. In a second series of model tests we further investigate the sensitivity of the simulated iron distribution fields in winter to the numbers chosen for the different iron sources (atmospheric deposition, iceberg melting, continental sediments) and the maximal DFe concentration in sea-ice. 

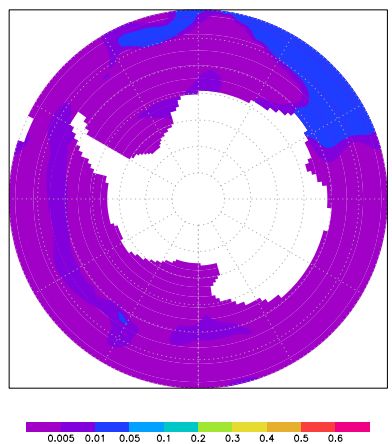

(a)
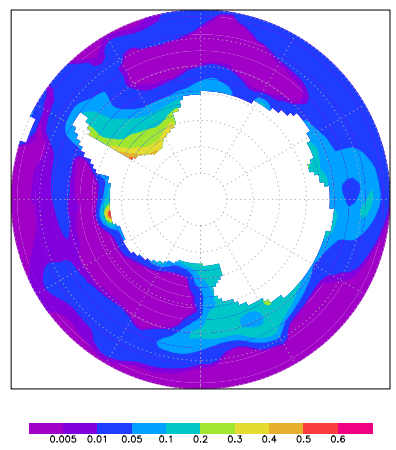

(c)
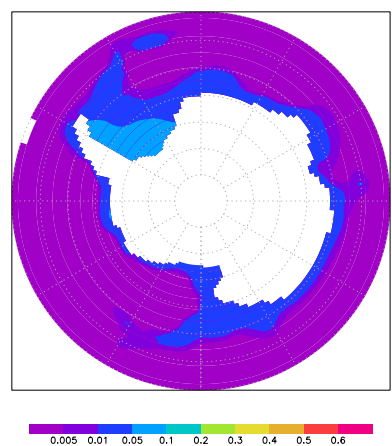

(b)

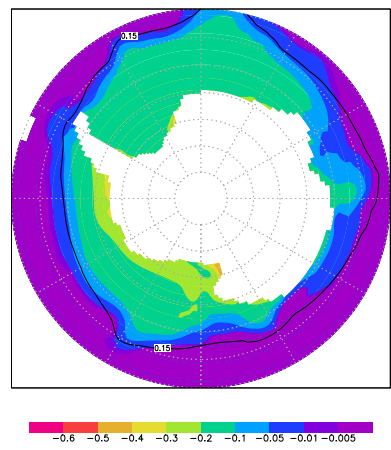

(d)
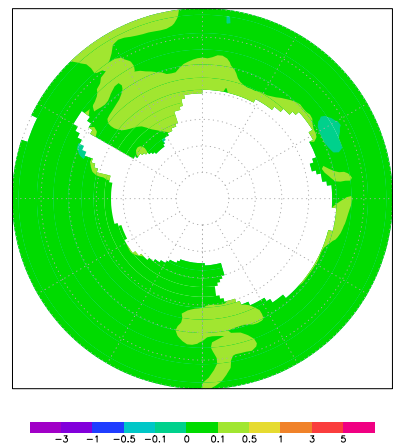

(a)

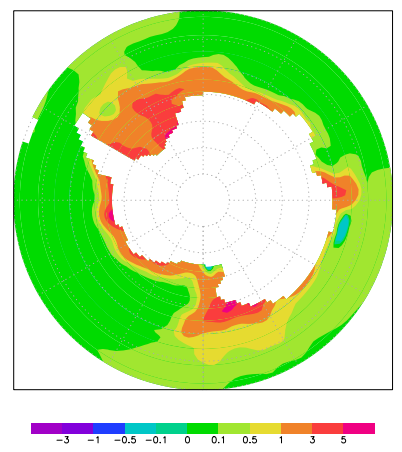

(c)

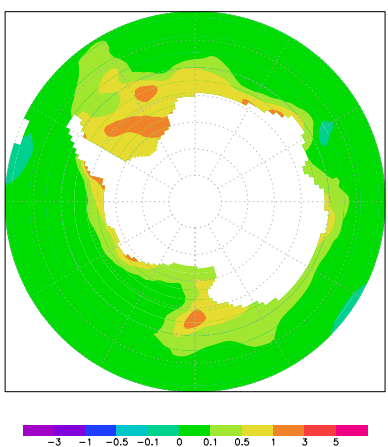

(b)

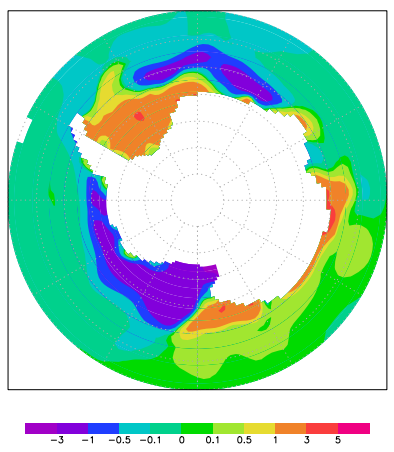

(d)
Fig. 9. Simulated effect of iron inputs from (a) atmosphere, (b) icebergs melting, (c) sediments on iron concentration $\left(\mu \mathrm{mol} \mathrm{Fe} \mathrm{m}{ }^{-3}\right)$ and of (d) the capture of iron in sea-ice on the winter (September) distribution of surface ocean DFe. The contribution of each component is obtained by subtracting results from the FULL experiment and the corresponding sensitivity experiment (Table 1). The September ice edge is displayed in contour. Values are averaged over the 1997-2000 period. Note that the color scale is not linear.

\subsection{Influence of the various sources of iron}

As expected from the forcing field (Fig. 1a), the effect of iron dust deposition on surface DFe (Fig. 9a) is globally low at high latitude in agreement with conclusions of Wagener et al. (2008) and Tagliabue et al. (2009). Interestingly however, the surface $\mathrm{DFe}$ enrichment due to atmospheric input (i.e. the difference between FULL and NOatm simulations; Fig. 9a) does not decrease in parallel with the forcing (Fig. 1a) but shows maximum values $\left(\sim 0.01 \mu \mathrm{mol} \mathrm{Fe}{ }^{-3}\right)$ in a quasi circumpolar band around $60^{\circ} \mathrm{S}$ and close to the continent around $45^{\circ}$ E. Relatively strong vertical movements are simulated by the model in those regions, indicating that the pattern of Fig. 9a is not related to the forcing itself but rather to the transport by ocean currents of dust iron from distant sources.

The contribution of icebergs is comparatively more significant than dust deposition, amounting to $0.1 \mu \mathrm{mol} \mathrm{Fe} \mathrm{m}^{-3}$ close to the coast of Antarctica (Fig. 9b). Contrasting with the geographical pattern associated with iron dust influence,

Fig. 10. Simulated effect of iron inputs from (a) atmosphere, (b) icebergs melting, (c) sediments and of (d) the capture of iron in seaice and release when melting on the spatial distribution of surface Chl- $a\left(\mathrm{mg} \mathrm{m}^{-3}\right)$ in December (a) and February (b, c, d). The contribution of each component is obtained by subtracting results from the FULL experiment and the corresponding sensitivity experiment (Table 1). The September ice edge is displayed in contour. Values are averaged over the 1997-2000 period. Note that the color scale is not linear.

the maximal iron releases from icebergs are predicted on the continental shelves and in bands located in the northern limbs of the Ross and Weddell Gyres, i.e. where the largest iceberg melting is observed (Gladstone et al., 2001). This suggests that ocean currents play a minor role in the horizontal redistribution of iron originating from iceberg melting.

Iron from sedimentary source has clearly the largest influence on the simulated surface DFe concentration (Fig. 9c). Neglecting this iron source has in many areas an one order of magnitude larger impact than dust deposition and iceberg melting (Fig. 9a, b, c). The largest differences $\left(>0.2 \mu \mathrm{mol} \mathrm{Fe} \mathrm{m}^{-3}\right)$ are found on the continental shelves due to the entrainment from below of iron from sedimentary sources by the vertical currents and intense mixing in winter (Fig. 4a). The iron is then transported horizontally from the shelf areas, mainly by the Ross and Weddell gyres, to the Antarctic circumpolar current. The surface divergence and the associated vertical currents in the model also play a role in the local maximum located around $60^{\circ} \mathrm{S}$ by inducing 
an upwelling of iron from depth, as already mentioned in the analysis of the effect of iron dust deposition. Interestingly model simulations are pointing two wide "iron-desert" zones in the eastern Weddell Sea and in the BellingshausenAmundsen Seas (Fig. 9c) that receive a very little fraction of the iron release from the sediments.

All the sensitivity experiments point to the major role of iron in limiting the simulated phytoplankton growth in the Southern Ocean (Fig. 10a, b, c): every tested source of iron contributes to an increase in the summer concentrations of surface Chl- $a$ that appears clearly related to the amount of iron provided and the subsequent changes in the iron winter stock (Fig. 9a, b, c).

The margin sediments constitute the major iron source to phytoplankton, with a 2 to 10 time larger enhancement of the simulated Chl- $a$ in February than that obtained by activating iceberg melting (Fig. 10b, c). Yet the added contribution of iron from iceberg melting might not be neglected, inducing an increase in surface Chl- $a$ of more than $1 \mathrm{mg} \mathrm{m}^{-3}$ in some regions of the Weddell Sea, off the west coast of the Antarctic Peninsula and in the outer Ross Sea (Fig. 10b). By contrast, the role of dust appears very minor on the Chl- $a$ distribution at high latitudes (Fig. 10a), as expected from Fig. 9a.

\subsection{Role of iron sequestration in sea ice}

Taking into account the iron capture and its storage by sea ice has a strong negative impact on the surface ocean DFe simulated in winter (Fig. 9d). The largest changes are simulated close to the coast, where ice production is significant and hence large ocean-to-ice iron fluxes take place. For instance, in the western Ross Sea, more than $10 \mathrm{~m}$ of ice per square meter are formed every year, leading to an annual mean iron uptake in sea ice from the ocean of $9 \mathrm{pmol} \mathrm{Fe} \mathrm{m}^{-2} \mathrm{~s}^{-1}$ $\left(0.8 \mu \mathrm{mol} \mathrm{Fe} \mathrm{m}^{-2} \mathrm{~d}^{-1}\right.$; Fig. 11b) i.e. of the same order of magnitude as iron sediment fluxes (Fig. 1c). The sea ice produced around the continent is then transported northward as shown by the high sea-ice DFe simulated in the northern limbs of the Ross and Weddell gyres (Fig. 6b). Ice motion ensures then a transport of iron from the continental shelf to deep ocean regions. This physical process also contributes to deplete oceanic DFe in the vicinity of the shelves where iceocean iron exchanges are activated (Fig. 9d). On the shelves, the iron loss due to its capture in the ice is compensated by inputs from sediments and iceberg melting, still allowing relatively high Fe concentrations at the ocean surface (Fig. 6a) as well as in the sea ice (Fig. 6b). By contrast, in many regions offshore, there is a net annual iron flux from sea ice to the ocean (Fig. 11b). Hence, iron transport by sea ice and its subsequent release through melting acts as a net source of iron for phytoplankton in those regions (Fig. 11a). The DFe iceocean fluxes are quite low in some regions such as the central Amundsen-Bellingshausen Sea $\left(<0.1 \mathrm{pmol} \mathrm{Fe} \mathrm{m}^{-2} \mathrm{~s}^{-1}\right.$; Fig. 11a) and can thus not compensate for the absence of large source of iron and of direct inflow of iron-rich waters
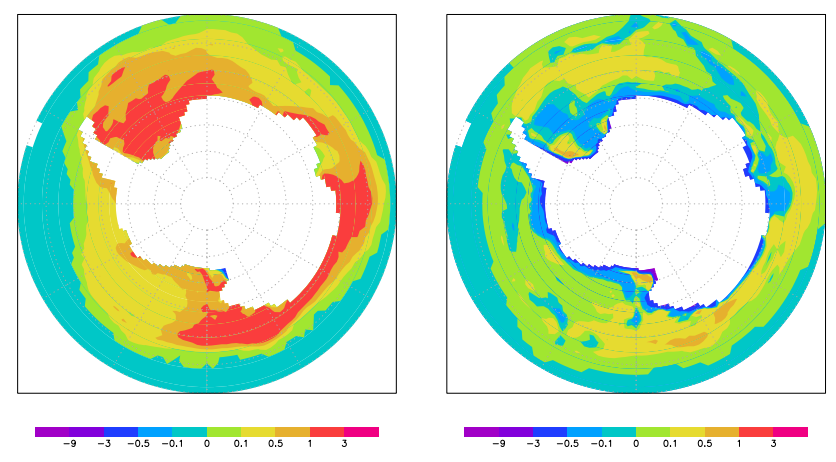

(a)

(b)

Fig. 11. Simulated iron fluxes between ocean and sea-ice for (a) summer (November-December-January) and (b) annual mean (pmol Fe m ${ }^{-2} \mathrm{~s}^{-1}$ ) averaged over the 1997-2000 period. The fluxes are positive when the iron is released into the ocean. Note that the color scale is not linear.

there (Fig. 1). The magnitude of the annual mean iron flux is largest in the Indian and western Pacific sector off Victoria Land as well as on the continental self of the Ross Sea just off shore of the coastal polynia (Fig. 11b). In those regions, a net annual melting is simulated (and thus a net import of ice on annual mean), inducing iron fluxes from sea ice to ocean that have the same magnitude or are even larger than those associated with wind, icebergs and sediment sources (Fig. 1).

In summer, because of the release of iron accumulated in sea ice when the latter melts, the iron fluxes at the iceocean interface are positive in the whole marginal ice domain (Fig. 11a). However, there is a high contrast between the relatively low values in the central Amundsen-Bellingshausen Sea and in the eastern Weddell Sea compared to the high values in the Western Weddell Sea, the Ross Sea and off East Antarctica. This is related to the large differences in the concentration of iron in sea ice between those regions (Fig. 6b).

Iron release associated to ice melting has no remarkable impact on the summer DFe concentration in the upper ocean, since the available DFe is nearly immediately taken up by phytoplankton. This is clearly suggested by Fig. 10d that shows a strong increase in the surface Chl- $a$ concentrations by 1 to $3 \mathrm{mg} \mathrm{m}^{-3}$ in the western Weddell Sea and off East Antarctica when the process of iron sequestration in ice and release is surface waters when ice melt is activated. However, in other regions as in the Ross, Belingshausen and Amundsen Seas as well as in the eastern Weddell Sea, the sequestration of iron in sea ice induces a decrease in Chl- $a$ (Fig. 10d). In those areas, the simulated release of iron from melting ice (Fig. 11a) is not sufficient to balance the yearlong decrease of oceanic iron concentration (Fig. 9d) due to sea ice capture and export out of these regions (Fig. 11). 
Table 3. Sensitivity to figures used for iron sources and maximal sea-ice concentration: statistical analysis.

\begin{tabular}{lcccc}
\hline Scenarios & Bias & SD & RMSE & CC \\
\hline FULL & 0.032 & 0.14 & 0.12 & 0.55 \\
ATMx2 & 0.04 & 0.15 & 0.12 & 0.54 \\
ATM/2 & 0.03 & 0.15 & 0.13 & 0.54 \\
ICBx2 & 0.05 & 0.15 & 0.13 & 0.53 \\
ICB/2 & 0.03 & 0.15 & 0.12 & 0.54 \\
SEDx2 & 0.12 & 0.2 & 0.19 & 0.40 \\
SED/2 & 0.02 & 0.13 & 0.10 & 0.55 \\
ICEx2 & 0.005 & 0.14 & 0.11 & 0.56 \\
ICE/2 & 0.07 & 0.16 & 0.14 & 0.44 \\
\hline
\end{tabular}

SD: Standard Deviation $\left(\mu \mathrm{mol} \mathrm{Fe} \mathrm{m}^{-3}\right)$

RMSE: Root Mean Square Error $\left(\mu \mathrm{mol} \mathrm{Fe} \mathrm{m}^{-3}\right)$

CC: Correlation Coefficient

SED: Sediment Fe source

ATM: atmospheric Fe input

ICB: Fe from iceberg melting

ICE: maximal Fe sea-ice concentrations

\subsection{Sensitivity to the magnitude of iron sources and storage potential in sea-ice}

In this section we investigate how the uncertainty on the numbers chosen for constraining the different DFe sources and maximal sea-ice concentration affects our model results and conclusions. A series of 16 sensitivity tests obtained by successively doubling and dividing by 2 each iron source or the maximum DFe concentration achieved in sea-ice were performed. The factor 2 differences have been preferred to the use of observed extreme values in order to facilitate the interpretation of the results. The obtained simulations of DFe were then statistically compared with observations (Table 3 ). The correspondence with observations was found as good as that shown for the reference run (FULL) except for DFe simulations obtained by doubling the sedimentary source or by dividing by 2 the maximum DFe concentration possibly reached in sea ice (Table 3 ).

The effect of changing DFe source/maximum sea-ice concentration was analyzed based on the mapping of the difference between the sensitivity test and the simulation lacking the considered tested iron source or sea-ice concentration (either NOatm or NOicb or NOsed or NOice; Fig. 12).

The crossed comparison between the different sensitivity tests confirms the low significance of atmospheric deposition (Fig. 12a, b) on the DFe availability when compared to other sources: iceberg melting (Fig. 12c,d) and sedimentary (Fig. 12e, f). The significant pattern obtained after doubling the iceberg-melting source (Fig. 12c) and dividing by 2 the sedimentary one (Fig. 12f) appears particularly interesting as both the tested values are well in the range of reported DFe sources. This comparison also highlights the
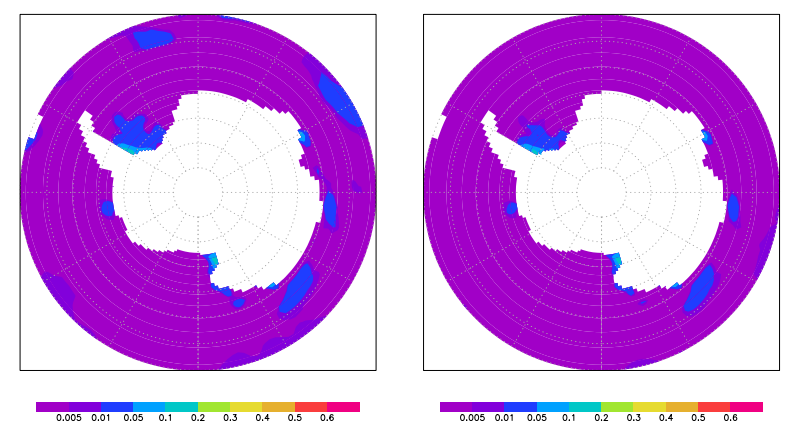

(a)
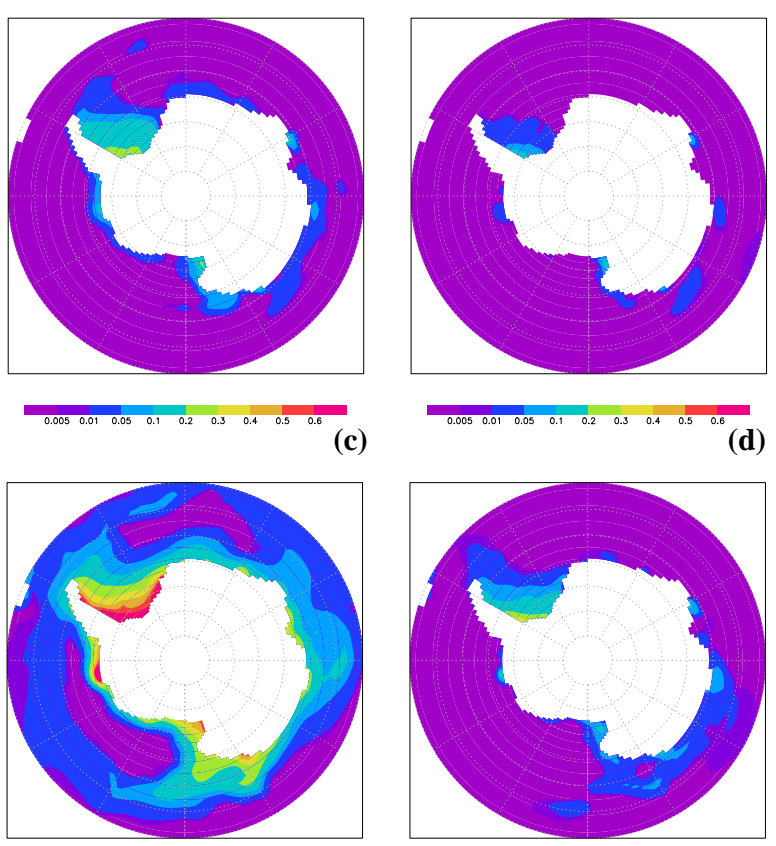

(e)

(f)
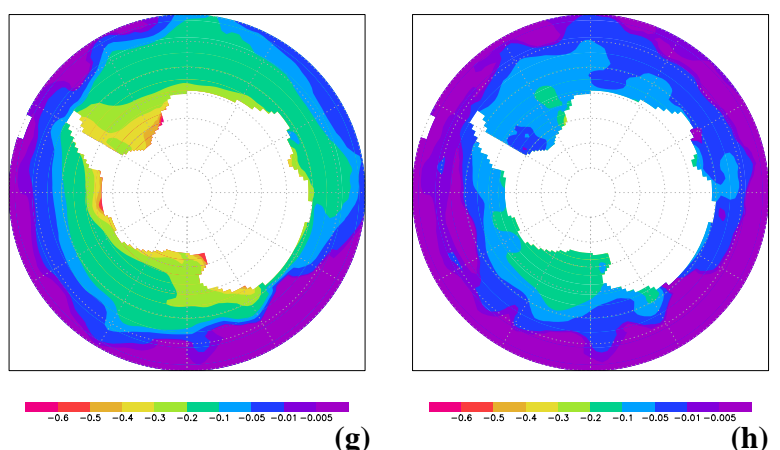

(h)

Fig. 12. Simulated effect of doubling (left) or dividing by 2 (right) the magnitude of the iron source from the atmosphere $(\mathbf{a}, \mathbf{b})$, iceberg melting (c, d), margin sediments $(\mathbf{e}, \mathbf{f})$ and of the iron concentration stored in sea-ice $(\mathbf{g}, \mathbf{h})$ on the DFe winter field. The effect of each iron source/storage is estimated from the difference between simulations obtained with the tested DFe value and those for which the corresponding iron source/storage is set to zero. Values are averaged over the 1997-2000 period. Note that the color scale is not linear. 
need for improvements in the estimates of both these sources, in particular regarding the role of icebergs in sustaining phytoplankton blooms in some regions of the Southern Ocean as it has been investigated in some observational studies (e.g. Schwarz and Schodlok, 2009) but not yet at large-scale in models.

The value chosen for the maximum DFe concentration stored in sea-ice has a strong impact on the regional distribution of DFe in winter and of surface Chl- $a$ in summer. As much as DFe is allowed to be captured in sea-ice as strong is the negative effect on DFe fields in winter, increasing the surface of regions around the continent with depleted DFe, especially the Ross, Bellinghaussen, Amundsen and Weddell Seas (Fig. 12g). On the contrary dividing by 2 the maximum DFe accumulated in sea-ice decreases significantly this negative effect and restrains its significance in the Amundsen Sea and West to the Ross Sea (Fig. 12h) where depleted surface DFe are simulated in winter (not shown). Clearly in our model, the DFe concentration possibly reached in sea-ice determines the distribution pattern of DFe available in spring/summer to phytoplankton and determines the asymmetric feature of the circumpolar phytoplankton blooms. Those sensitivity studies show thus clearly the potential influence of the storage of iron in sea ice and of its subsequent release on both the location and the magnitude of the blooms. Our experiments, which describe the first attempt to incorporate those processes in simulations covering the whole Southern Ocean, also underline the large current uncertainty and thus the critical need of an improved representation of the ice-ocean exchanges of iron in models.

\section{Conclusions}

The availability of dissolved iron in combination with light shapes the geographical distribution of phytoplankton growth in the Southern Ocean. Model results suggest the following combination of factors to explain that large summer phytoplankton blooms occur near the shelf and the retreating ice-edge: iron availability, abundance of major nutrients, relatively shallow mixed layers and low ice concentrations that permit enough light penetrating through the water column. Comparing the contribution of best estimates for various iron sources leads to the conclusion that sediments are a major iron supplier to Southern Ocean waters as also suggested by Tagliabue et al. (2009). The magnitude of sedimentary iron input as well as its capture by ice during its formation explains why large oceanic DFe concentrations are found in the vicinity of the continental shelves and in the marginal ice zone. While the dust contribution as an iron source is very weak, icebergs also have a non-negligible effect on the DFe distribution at the ocean surface and thus on the Chl- $a$ concentrations. However, we have considered here smooth, large-scale, average conditions for iceberg melting while icebergs lead in reality to highly heterogeneous fluxes, both in space and time. An analysis of the impact of individual icebergs would certainly have lead punctually to a much larger influence of iceberg melting, which could be dominant on the tracks of large icebergs (Smith et al., 2007; Schwarz and Schodlok, 2009).

The sequestration of iron in sea ice is not a source of iron per se but it contributes to redistribute DFe regionally, by transporting iron, and seasonally, by storing iron in winter and releasing it in summer. In the western Weddell Sea and off East Antarctica, this induces a summer increase in surface Chl- $a$, mainly because iron is released in the upper ocean at the time when the mixed layer is shallow providing phytoplankton with sufficient iron and light for blooming. However, the effect is opposite in the Ross, Bellingshausen, Amundsen seas and in the eastern Weddell Sea because sea-ice iron is exported from those region by sea ice transport. Of course, this counterintuitive effect is seen only when analyzing the long-term influence of the sequestration and transport of iron by sea ice on the whole ice-ocean system. In summer, the melting of the sea ice is accompanied by iron release that constitutes a source for marginal ice zone phytoplankton. Neglecting only the summer release of iron would have thus lead to a significant decrease of simulated Chl- $a$, as expected. This agrees with earlier observations and model studies underlining the role of iron release in sustaining summer blooms in the Ross Sea (Sedwick and Di Tullio, 1997; Tagliabue and Arrigo, 2006) and near the continent (Fitch and Moore, 2007). Nevertheless, iron concentration in sea ice is so low in some regions of the eastern Weddell Sea and of the Bellingshausen-Amundsen Sea that the summer melting releases very low iron to the ocean. As a consequence, no bloom is associated with the receding ice edge as observed there (Fig. 8), in contrast with other regions of the Southern Ocean. This result agrees with and explains the high variations of phytoplankton blooms in the circumpolar marginal ice zone reported by SeaWIFS (Fig. 8; Fitch and Moore, 2007). Hence it appears crucial to taking this spatial heterogeneity into account for a better understanding of the ecosystem dynamics in the Southern Ocean.

There are large uncertainties on the magnitude of each iron source and process. For instance, the flux associated with iceberg melting could have been increased by one order of magnitude at least (Raiswell et al., 2008). The potential range in sediment fluxes is also very large. In addition, the mechanisms associated with the sea-ice iron capture and release to the ocean are not well known justifying our choice for a very simple parameterization. Improvements in both the estimates of the sources and on the representation of iceocean exchanges are thus clearly required before any reasonable quantitative estimate of the relative influence of each of the source and of the sequestration of iron in sea ice could be assessed. Nevertheless, the dominant contributions as iron source of sediments and of iceberg melting appear qualitatively robust in our sensitivity study. Furthermore, we have underlined some important mechanisms that are independent 
of the exact value used for each of the sources. We have clearly shown that on time scales longer than the seasonal cycle, sea ice sequestration and release should not only be considered as a summer source of iron for the water column but also as a way of transporting sea ice from one region to another one. Furthermore, the amount of iron that could be released in summer appears strongly related to the availability of iron in the water column in winter. Sea ice is thus not a "universal iron supplier", for all the regions explaining the heterogeneous spatial pattern of marginal ice blooms. A significant release during melting could be found only if sources are present in the area (from sediments or iceberg melting) or if sea ice is transported from a remote location where a high iron concentration in the ocean was observed at the time of ice formation.

Acknowledgements. H. Goosse is Research Associate and M. Vancoppenolle is Postdoctoral Researcher with the Fonds National de la Recherche Scientifique (FNRS-Belgium). Benedicte Pasquer acknowledges support from the Australian Commonwealth Cooperative Research Centres Program. This work was funded by the Belgian Federal Science Policy Office, Research Program on Science for a Sustainable Development in the scope of the BELCANTO project and the Belgian French Community 'Action de Recherche Concertée' in the scope of the SIBCLIM project. Analyses and visualizations used in this study were produced with the Giovanni online data system, developed and maintained by the NASA Goddard Earth Sciences (GES) Data and Information Services Center (DISC). The present study is a Belgian contribution to the SOLAS and ICED international research initiatives and the European Network of Excellence EUR-OCEANS.

Edited by: L. Bopp

\section{References}

Acker,J. G. and Leptoukh G.: Online Analysis Enhances Use of NASA Earth Science Data, Eos, Trans. AGU, 88(2), 14-17, 2007.

Aguilar-Islas, A. M., Rember, R. D., Mordy, C. W., and Wu, J.: Sea ice-derived dissolved iron and its potential influence on the spring algal bloom in the Bering Sea, Geophys. Res. Lett., 35, L24601, doi:10.1029/2008GL035736, 2008.

Arrigo, K. R., Worthen, D., Schnell, A., and Lizotte, M. P.: Primary production in Southern Ocean waters, J. Geophys. Res., 103, 1007-1021, 1998.

Arrigo, K. R., van Dijken, G. L., and Bushinsky, S., Primary production in the Southern Ocean, 1997-2006, J. Geophys. Res., 113, C08004, doi:10.1029/2007JC004551, 2008.

Atkinson, A., Siegel, V., Pakhomov, E., and Rothery, P.: Longterm decline in krill stocks and increase in salps in the Southern Ocean, Nature, 432, 100-103, 2004.

Aumont, O. and Bopp, L.: Globalizing results from ocean in situ iron fertilization studies. Global Biogeochem. Cy., 20, GB2017, doi:10.1029/2005GB002591, 2006.
Aumont, O., Maier-Reimer, E., Blain, S., and Monfray, P.: An ecosystem model of the global ocean including $\mathrm{Fe}$, Si, P co-limitations, Global Biogeochem. Cy., 17(2), 1060, doi:10.1029/2001GB001745, 2003.

Beckmann A. and Döscher R.: A method for improved representation of dense water spreading over topography in geopotentialcoordinate models, J. Phys. Oceano., 27(4), 581-591, 1997.

Berliand, M. E. and Strokina, T. G.: Global distribution of the total amount of clouds, Hydrometeorological Report, St. Petersburg, Russia, 77 pp., 1980 (in Russian).

Blain, S., Quéguiner, B., Armand, L., Belviso, S., et al.: Effects of natural iron fertilization on carbon sequestration in the Southern Ocean, Nature, 446, 1070-1074, 2007.

Blanke, B. and Delecluse, P.: Low frequency variability of the tropical Atlantic Ocean simulated by a general circulation model with mixed layer physics, J. Phys. Oceano., 23, 1363-1388, 1993.

Boyd, P. W., Jickells, T., Law, C., Blain, S., et al.: Mesoscale iron-enrichment experiments 1993-2005, Science, 315, 612617, 2007.

Boye, M., van den Berg, C. M. G., de Jong, J. T. M., Leach, H., Croot, P., and de Baar, H. J. W.: Organic complexation of iron in the Southern Ocean, Deep-Sea. Res. Pt. I, 48, 1477-1497, 2001.

Coale, K. H., Gordon, R.M ., and Wang, X.:The distribution and behavior of dissolved and particulate iron and zinc in the Ross Sea and Antarctic Circumpolar Current along $170^{\circ} \mathrm{W}$, Deep-Sea Res. Pt. I, 52, 295-318, 2005.

Church, J. A., Gregory, J. M., Huybrechts, P., Kuhn, M., Lambeck, K., Nhuan, M. T., Quin, D., and Woodworth, P. L.: Changes in sea level, in: Climate Change 2001: The Scientific Basis, Contribution of Working Group I to the third Assessement Report of the Intergovernmental Panel on Climate Change, edited by: Houghton, J. T., Ding, Y., Griggs, D. J., Noguer, P. J., van der Linden, M., Dai, X., Maskell, K., and Johnson, C. A, Cambridge University Press, Cambridge, 639-693, 2001.

Croot, P. L., Andersson, K., Oztürk, M., and Turner, D.: The distribution and speciation of iron along $6^{\circ} \mathrm{E}$, in the Southern Ocean, Deep-Sea Res. Pt. II, 51, 2857-2879, 2004.

de Baar, H. J. W., Buma, A. G. J., Nolting, R. F., Cadee, G. C., Jacques, G., and Treguer, P. J.: On iron limitation of the Southern Ocean: experimental observations in the Weddell and Scotia seas, Mar. Ecol. Prog. Ser., 65, 105-122, 1990.

de Baar, H. J. W, de Jong, J. T. M, Bakker, D. C. E., Löscher, B. M., Veth, C., Bathmann, U., and Smetacek, V.: The importance of iron for phytoplankton blooms and carbon dioxide drawdown in the Southern Ocean, Nature, 373, 412-415, 1995.

de Baar, H. J. W., de Jong, J. T. M., Nolting, R. F., Timmermans, K. R., van Leeuwe, M. A., Bathmann, U., Rutgers van der Loeff, M., and Sildam, J.: Low dissolved Fe and the absence of diatom blooms in remote Pacific waters of the Southern Ocean, Mar. Chem., 66, 1-34, 1999.

de Baar, H. J. W, Boyd, P. W., Coale, K. H., Landry, M. R., et al.: Synthesis of iron fertilization experiments: from the iron age in the age of enlightenment, J. Geophys. Res.-Oceans, 110, C09S16, doi:10.1029/2004JC002601, 2005.

de Boyer Montégut, C., Madec, G., Fischer, A. S., Lazar, A., and Ludicone, D.: Mixed layer depth over the global ocean : An examination of profile data and a profile-based climatology, J. Geophys. Res., 109, C12003, doi:10.1029/2004JC002378, 2004. 
de Jong, J. T. M., den Das, J., Bathmann, U., Stoll, M. H. C., Kattner, G., Nolting, R. F., and de Baar, H. J. W.: Dissolved iron at subnanomolar levels in the Southern Ocean as determined by ship-board analysis, Anal. Chim. Acta, 377, 113-124, 1998.

de Jong, J., Lannuzel, D., Tison, J.-L., de Baar, H. W. J., and Schoemann, V.: Iron inputs into the Antarctic Circumpolar Current from continental shelf sources: towards a dissolved iron budget for the Southern Ocean, in preparation, 2009.

de Montety, A.: Comparison between open and closed boundary conditions: a study performed with the NEMO model. Scientific report 2006/02, Institut d'Astronomie et de Géophysique G. Lemaître, Université Catholique de Louvain, Belgium, 2006.

Duce, R. A. and Tindale, N. W.: Chemistry and biology of iron and other trace metals, Limnol. Oceanogr., 36(8), 1715-1726, 1991.

Dutkiewicz, S., Follows, M. J., and Parekh, P.: Interactions of the iron and phosphorus cycles: A threedimensional model study, Global Biogeochem. Cy., 19, GB1021, doi:10.1029/2004GB002342, 2005.

Elrod, V. A., Berelson, W. M., Coale, K. H., and Johnson, K. $\mathrm{S}$ : The flux of iron from continental shelf sediments: a missing source for global budgets, Geophys. Res. Lett., 31, L12307, doi:10.1029/2004GL020216, 2004.

Fan, S.-M., Moxim, W. J., and Levy, I. I. H.: Aeolian input of bioavailable iron to the ocean, Geophys. Res. Lett., 33, L07602, doi:10.1029/2005GL024852, 2006.

Fichefet, T. and Morales Maqueda, M. A.: Sensitivity of a global sea ice model to the treatment of ice thermodynamics and dynamics, J. Geophys. Res., 102(C6), 12609-12646, 1997.

Fitch, D. T. and Moore, K. J.: Wind speed influence on phytoplankton bloom dynamics in the Southern Ocean Marginal Ice Zone, J. Geophys. Res., 112, C08006, doi:10.1029/2006JC004061, 2007.

Fitzwater, S. E., Johson, K. S., Gordon, R. M., Coale, K. H., and Smith Jr, W. O.: Trace metal concentration in the Ross Sea and their relationship with nutrient and phytoplankton growth, DeepSea Res. Pt. II, 47, 3159-3179, 2000.

Fung, I. Y., Meyn, S. K., Tegan, I., Doney, S. C., John, J. G., and Bishop, J. K. B.: Iron supply and demand in the upper ocean, Global Biogeochem. Cy., 14, 281-295, 2000.

Gladstone, R. M., Bigg, G. R., and Nichols, K. W.: Iceberg trajectory modeling and meltwater injection in the Southern Ocean, J. Geophys. Res., 106(C9), 19903-19915, 2001.

Gent, P. R. and McWilliams J. C.: Isopycnal mixing in ocean circulation models, J. Phys. Oceanogr., 20, 150-155, 1990.

Ginoux, P., Chin, M., Tegen, I., Prospero, J. M., Holben, B., Dubovik, O., and Lin, S.-J. : Sources and distributions of dust aerosols simulated with the GOCART model, J. Geophys. Res., 106(D17), 20255-20273, 2001.

Goosse, H.: Modelling the large-scale behaviour of the coupled ocean - sea-ice system. Ph.D. thesis, Université Catholique de Louvain, Louvain-la-Neuve, Belgium, 1997.

Gregg, W. W., Ginoux, P., Schopf, P. S., and Casey, N. W.: Phytoplankton and iron: validation of a global three-dimensional ocean biogeochemical model, Deep-Sea Res. Pt. II, 50, 31433169, 2003.

Greene, R. M., Geider, R. J., and Falkowski, P. G.: Effect of iron limitation on photosynthesis in a marine diatom, Limnol. Oceanogr., 36, 1772-1782, 1991.
Griffies, S. M., Biastoch, A., Boning, C., Bryan, F., et al.: Coordinated Ocean-ice Reference Experiments (COREs), Ocean Model., 26(1-2),1-46, 2009.

Grotti, M., Soggia, F., Ianni, C., and Frache, R.: Trace metals distributions in coastal sea ice of Terra Nova Bay, Ross Sea, Antarctica, Antarct. Sci., 17(2), 289-300, 2005.

Hibler, W. D.: A dynamic thermodynamic sea ice model, J. Phys. Oceanogr., 9, 815-846, 1979.

Hines, K. M., Bromwich, D. H., and Marshall, G. J.: Artificial surface pressure trends in the NCEP-NCAR reanalysis over the Southern Ocean and Antarctica, J. Clim., 13, 3940-3952, 2000.

Ho, T. Y., Quigg, A., Finkel, Z. V., Milligan, A. J., Wyman, K., Falkowski, P. G., and Morel, F. M. M.: The elemental composition of some marine phytoplankton, J. Phycol., 39(6), 11451159, 2003.

Jackett, D. R. and Mc Dougall, T. J.: Stabilization of hydrographic data, J. Atmos. Oceanic Technol., 12, 381-389, 1995.

Jickells, T. D., An, Z. S., Andersen, K. K., Baker, A. R., et al.: Global iron connections between desert, dust, ocean biogeochemistry and climate, Science, 308, 67-71, 2005.

Johnson, K. S.: Iron supply and demand to the upper ocean: is extraterrestrial dust a significant source of bioavailable iron? Glob. Biogeochem. Cy., 15(1), 61-63, 2001.

Johnson, K. S., Gordon, M. R., and Coale, K. H.: What controls dissolved iron concentrations in the world ocean?, Mar. Chem., 57, 137-161, 1997.

Kalnay, E., Kanamitsu, M., Kistler, R., et al.: The NCEP/NCAR 40year reanalysis project, Bull. Am. Meteorol. Soc., 77, 437-470, 1996.

Lancelot, C., Veth, C., and Mathot, S.: Modelling ice edge phytoplankton bloom in the Scotia Weddell Sea sector of the Southern Ocean during spring 1988, J. Mar. Syst, 2, 333-346, 1991.

Lancelot, C., Mathot, S., Veth, C., and de Baar, H. W. J.: Factors controlling phytoplankton ice-edge blooms in the marginal ice-zone of the north western Weddell Sea during sea ice retreat 1988: field observations and mathematical modelling, Polar Biol., 13, 377-387, 1993.

Lancelot, C., Hannon, E., Becquevort, S., Veth, C., and de Baar H. J. W.: Modeling phytoplankton blooms and carbon export production in the Southern Ocean: dominant controls by light and iron in the Atlantic sector in Austral spring 1992, Deep-Sea Res. Pt. I, 47, 1621-1662, 2000.

Lannuzel, D., de Jong, J. T. M., Schoemann, V., Trevena, A., Tison, J.-L., and Chou, L.: Development of a sampling and flow injection analysis technique for iron determination in the sea ice environment, Anal. Chim. Acta, 556, 476-483, 2006.

Lannuzel, D., Schoemann, V., de Jong, J. T. M., Tison, J.-L., and Chou, L.: Distribution and biogeochemical behaviour of iron in the East Antarctic sea ice, Mar. Chem., 106(1-2), 18-32, 2007.

Lannuzel, D., Schoemann, V., de Jong, J. T. M., Chou, L., Delille, B., Becquevort, S., and Tison, J.-L.: Iron study during a time series in the western Weddell pack ice, Mar. Chem., 108, 85-95, 2008.

Lefebvre, W. and Goosse, H.: Influence of the southern annular mode on the sea ice-ocean system: The role of the thermal and mechanical forcing, Ocean Sci., 1(2), 145-157, 2005. 
Lefebvre, W. and Goosse, H. : Analysis of the projected regional sea ice changes in the Southern Ocean during the 21st century, Clim. Dynam., 30, 59-76, 2008.

Lefebvre, W., Goosse, H., Timmermann, R., and Fichefet,T.: Influence of the southern annular mode on the sea ice-ocean system, J. Geophys. Res., 109, C09005, doi:10.1029/2004JC002403, 2004.

Levitus, S.: NODC (Levitus) World Ocean Atlas 1998 data, report: NOAA-CIRES, Clim. Diag. Cent. Boulder, Colorado, 1998.

Li, M. and Garett, C.: Mixed Layer Deepening Due to Langmuir Circulation, J. Phys. Oceanogr., 27, 121-132, 1997.

Löscher, B. M., de Baar, H. J. W., de Jong J. T. M., Veth, C., and Dehairs, F.: The distribution of Fe in the Antarctic Circumpolar Current, Deep-Sea Res. Pt. II, 44, 143-187, 1997.

Luo, C., Mahowald, N. M., and del Corral, J.: Sensitivity study of meteorological parameters on mineral aerosol mobilization, transport, and distribution, J. Geophys. Res., 108(D15), 4447, doi:10.1029/2003JD003483, 2003.

Madec, G., Delecluse, P., Imbard, M., and Lévy, C.: OPA 8.1 Ocean General Circulation Model reference manual, Notes du Pôle de Model, Inst. Pierre-Simon Laplace (IPSL), France, No 11, 91 pp., 1999.

Madec, G.: NEMO ocean engine*. Note du Pole de modélisation, Institut Pierre-Simon Laplace (IPSL), France, No 27, ISSN No 1288-1619, 2008.

Mahowald, N. M., Baker, A. R., Bergametti, G., Brooks, N., Duce, R. A., Jickells, T. D., Kubilay, N., Prospero, J. M., and Tegen, I.: Atmospheric global dust cycle and iron inputs to the ocean, Global Biogeochem. Cy., 19, GB4025, doi:10.1029/2004GB002402, 2005.

Masson, F., de Jong, J. T. M., Dumont, I., Becquevort, S., Tison, J-L., and Schoemann, V.: Temporal evolution of iron distribution in the Antarctic pack ice zone, Bellingshausen Sea, in preparation, 2009.

Mathiot, P.: Influence du forçage atmosphérique sur la représentation de la glace de mer et des eaux de plateau en Antarctique dans une étude de modélisation numérique, Ph.D. thesis, Université Joseph Fourier, Grenoble, France, 2009.

Merryfield W. J., Holloway G., and Gargett A. E.: 1999. A global ocean model with double-diffusive mixing, J. Phys. Oceanogr., 29, 1124-1142, 2005.

Mitchell, B. G., Brody, E. A., Holm-Hansen, O., McClain, C., and Bishop, J.: Light limitation of phytoplankton biomass and macronutrient utilization in the Southern Ocean, Limnol. Oceanogr., 36, 1662-1677, 1991.

Molines, J. M., Treguier, A. M., and Talandier, C.: Open Boundaries Conditions in EOSF, Internal report, Laboratoire d'Océanographie DYnamique et de Climatologie, Institut Pierre Simon Laplace des Sciences de l'Environnement Global, France, 2003.

Moore, J. K. and Abbott, M. R.: Phytoplankton chlorophyll distribution and primary production in the Southern Ocean, J. Geophys. Res., 105, 28709-28722, 2000.

Moore, J. K., Doney, S. C., and Lindsay, K.: Upper ocean ecosystem dynamics and iron cycling in a global threedimensional model, Global Biogeochem. Cy., 18, GB4028, doi:10.1029/2004GB002220, 2004.

Moore, J. K. and Braucher, O.: Sedimentary and mineral dust sources of dissolved iron to the world ocean, Biogeosciences, 5, 631-656, 2008, http://www.biogeosciences.net/5/631/2008/.
Nolting, R. F., de Baar, H. J. W., van Bennekom, A. J., and Masson, A.: Cadmium, copper and iron in the Scotia Sea, Weddell Sea and Weddell/Scotia Confluence (Antarctica), Mar. Chem., 35, 219-243, 1991.

Olson, R. J.: ${ }^{15}$ Ntracer studies of the primary nitrite maximum, J. Mar. Res., 39, 203-226, 1981.

Parekh, P., Follows, M. J., and Boyle, E. A.: Decoupling of iron and phosphate in the global ocean, Global Biogeochem. Cy., 19, GB2020, doi:10.1029/2004GB002280, 2005.

Pasquer, B., Laruelle, G., Becquevort, S., Schoemann, V., Goosse, H., and Lancelot, C.: Linking biogeochemical cycles and ecosystem structure and function: results of the complex SWAMCO-4 model, J. Sea Res., 53, 93-108, 2005.

Pollard, R., Sanders, R., Lucas, M., and Statham, P.: The Crozet Natural Iron Bloom and Export Expertiment (CROZEX), DeepSea Res Pt. II, 54, 1905-1914, 2007.

Pollard, R. T., Salter, I., Sanders, R. J., Lucas, M. I., et al.: Southern Ocean deep-water carbon export enhanced by natural iron fertlization, Nature, 457, 577-580, 2009.

Preunkert, S., Legrand, M., Jourdain, B., Moulin, C., Belviso, S., Kasamatsu, N., Fukuchi, M., and Hirawake, T.: Interannual variability of dimethylsulfide in air and seawater and its atmospheric oxidation by-products (methanesulfonate and sulfate) at Dumont d'Urville, coast Antarctica (1999-2003), J. Geophys. Res., 112, D06306, doi:10.1029/2006JD007585, 2007.

Raiswell, R., Benning, L. G., Tranter, M., and Tulaczyk, S.: Bioavailable iron in the Southern Ocea: the significance of the iceberg conveyor belt, Geochemical Transactions, 9(7), doi:10.1186/1467-4866-9-7, 2008.

Rayner, N., Parker, D., Horon, E., Folland, C., Alexander, L., Rowel, D., Kent, E., and Kaplan, A.: Global analyses of sea surface temperature, sea ice and night marine air temperature since the late nineteenth century, J. Geophys. Res., 108(D14), 4407, doi:10.1029/2002JD002670, 2003.

Schwarz, J. N. and Schodlock, M. P.: Impact of drifting icebergs on surface phytoplankton biomass in the Southern Ocean: Ocean colour remote sensing and in situ iceberg tracking, Deep-Sea Res. Pt. I, 56, 1727-1741, 2009.

Sedwick, P. N. and Di Tullio, G. R.: Regulation of algal blooms in Antarctic shelf waters by the release of iron from melting sea ice, Geophys. Res. Lett., 24, 2515-2518, 1997.

Sedwick, P. N., Di Tullio, G. R., Hutchins, D. A., Boyd, P. W., Griffiths, F. B., Crossley, A. C., Trull, T. W., and Queguiner, B.: Limitation of algal growth by iron deficiency in the Australian subantarctic region, Geophys. Res. Lett., 26, 2865-2868, 1999.

Semtner, A.: A model for the thermodynamic growth of sea ice in numerical investigations of climate, J. Phys. Oceanogr., 6, 379389, 1976.

Sigman, D. M. and Boyle, E. A.: Glacial/interglacial variations in atmospheric carbon dioxide, Nature, 407, 859-869, 2000.

Smith, Jr., W. O. and Nelson, D. M.: Phytoplankton bloom produced by a receding ice-edge in the Ross Sea: spatial coherence with the density field, Science, 227, 163-166, 1985.

Smith, K. L., Robinson, B. H., Helly, J. J., Kaufmann, R. S., et al.: Free-drifting icebergs: hot spots of chemical and biological enrichment in the Weddell Sea, Science, 317, 478-482, 2007. 
Sohrin, Y., Iwamota, S., Matsui, M., Obata, H., Nakayama, E., Suzuki, K., Handa, N., and Ishii, M.: The distribution of Fe in the Australian sector of the Southern Ocean, Deep-Sea Res. Pt. I, 47, 55-84, 2000.

Tagliabue, A. and Arrigo, K. R.: Processes governing the supply of iron to phytoplankton in stratified seas, J. Geophys. Res, 111, C06019, doi:10.1029/2005JC003363, 2006.

Tagliabue, A., Bopp, L., and Aumont, O.: Ocean biogeochemistry exhibits contrasting responses to a large scale reduction in dust deposition, Biogeosciences, 5, 11-24, 2008, http://www.biogeosciences.net/5/11/2008/.

Tagliabue, A., Bopp, L., and Aumont, O.: Evaluating the importance of atmospheric and sedimentary iron sources to Southern Ocean biogeochemistry, Geophys. Res. Lett., 36, L13601, doi:10.1029/2009GL038914, 2009.

Tegen, I. and Fung, I.: Contribution to the atmospheric mineral aerosol load from land surface modification, J. Geophys. Res., 100, 18707-18726, 1995.

Timmermann, R., Beckmann, A., and Hellmer, H. H.: Simulations of ice-ocean dynamics in the Weddell Sea 1. Model configuration and validation, J. Geophys. Res.-Oceans, 107(C3), 3024, doi:10.1029/2000JC000741, 2002.

Timmermann, R., Worby, A., Goosse, H., and Fichefet, T.: Utilizing the ASPeCt sea ice thickness data set to validate a global coupled sea ice - ocean model, J. Geophys., 109, C07017, doi:10.1029/2003JC002242, 2004.

Timmermann ,R., Goosse, H., Madec, G., Fichefet, T., Ethe, C., and Dulière, V.: On the representation of high latitude processes in the ORCALIM global coupled sea ice-ocean model, Ocean Model., 8(1-2), 175-201, 2005.
Timmermans, K. R., van der Wagt, B., and de Baar, H. J. W.: Growth rates, half saturation constants, and silicate, nitrate, and phosphate depletion in relation to iron availability of four large open-ocean diatoms from the Southern Ocean, Limol. Oceanogr., 49(6), 2141-2151, 2004.

Trenberth, K. E., Olson, J. G., and Large, W. G. : A global ocean wind stress climatology based on the ECMWF analyses, Natl. Cent. for Atmos. Res., Boulder, Colorado, USA, NCAR/TN338+STR, 93 pp., 1989.

Twining, B. S., Baines, S. B., Fisher, N. S., and Landry, M. R.: Cellular iron contents of plankton during the Southern Ocean iron Experiment (SOFeX), Deep-Sea Res. Pt. I, 51, 1827-1850, 2004.

Vancoppenolle, M., Fichefet, T., Goosse, H., Bouillon, S., Madec, G., and Morales Maqueda, M. A.: Simulating the mass balance and salinity of Arctic and Antarctic sea ice. I. Model description and validation, Ocean Model., 27, 33-53, doi:10.1016/j.ocemod.2008.10.005, 2009a.

Vancoppenolle, M., Goosse, H., de Montety, A., Fichefet, T., Tremblay, B., and Tison, J.-L.: Modeling brine and nutrient dynamics in Antarctic sea ice: the case of dissolved silica, J. Geophys. Res., doi:10.1029/2009JC005369, in press, 2009b.

Wagener, T., Guieu, C., Losno, R., Bonnet, S., and Mahowald, N.: Revisiting atmospheric dust export to the Southern Hemisphere ocean: Biogeochemical implications, Global Biogeochem. Сy., 22, GB2006, doi:10.1029/2007GB002984, 2008.

Xie, P. and Arkin, P. A.: Analyses of global monthly precipitation using gauge observations, satellite estimates and numerical model predictions, J. Clim., 9, 840-858, 1996. 